\title{
INDIGENOUS ENVIRONMENTAL RIGHTS IN CANADA: THE RIGHT TO CONSERVATION IMPLICIT IN TREATY AND Aboriginal Rights to Hunt, Fish, AND TraP
}

\author{
LyNDA M. COLLINS* AND MEghan MURTHA**
}

This article is an exploration of Aboriginal and treaty rights strategies for protecting Indigenous environmental rights in Canada. The analysis begins with an outline of the problem, and the shortcomings of the available general law avenues. The authors then argue for the existence of a constitutionalized right to environmental preservation implicit in treaty and Aboriginal rights to hunt, fish, and trap. The article explores the theoretical, historical, and precedential support for this proposition. The central argument is that in securing the right to hunt, fish, and trap, Aboriginal peoples were in fact contracting for the continued existence of their traditional subsistence activities. These practices could not survive without the preservation of the ecosystems on which they depend, and the harvesting rights must therefore be seen to encompass a right to such preservation. Examination of the specific histories of treaty-making in Canada reveals that in many if not most cases, both the Crown and the Aboriginal signatories understood this substantive protection to be a part of the treaty guarantees. The authors then present a brief articulation of the corresponding Aboriginal right to conservation.
Cet article explore les stratégies des droits autochtones et des droits conférés par traité pour protéger les droits environnementaux indigènes au Canada. L'analyse commence par un énoncé du problème et des faiblesses des approches juridiques généralement possible. Les auteurs font valoir les mérites de l'existence d'un droit constitutionnalisé à la préservation environnementale qui serait implicite dans les droits autochtones et les droits conférés par traité relatifs à la chasse, la pêche et la trappe. L'article examine le soutien théorique, historique et de préséance de cette proposition. Au centre du débat est le fait qu'en obtenant le droit de chasser, de pêcher et de trapper, les peuples autochtones s'engageaient à maintenir l'existence de leurs activités traditionnelles de subsistance. Ces pratiques ne pourraient pas survivre sans la préservation des écosystèmes dont elles dépendent; les droits de récolte doivent donc être interprétés de manière à englober le droit à cette préservation. L'étude de la conclusion de traités précis au Canada révèle que dans de nombreux cas, sinon la plupart, à la fois les signataires représentant la Couronne et les Autochtones avaient compris que cette protection importante faisait partie des garanties $d u$ traité. Les auteurs traitent un peu du droit autochtone correspondant à la conservation.

\section{TABLE OF CONTENTS}

I. InTRODUCTION .............................. 960

II. PROTECTIONS FOR INDIGENOUS ENVIRONMENTAL RIGHTS

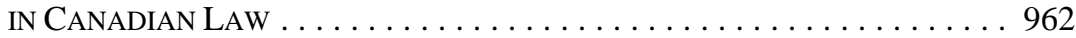

III. ABORIGINAL LAW SOURCES OF INDIGENOUS

ENVIRONMENTAL RIGHTS IN CANADA . . . . . . . . . . . . . . 964

A. The CROWN's FiduCIARY DUTY . . . . . . . . . . . . . . . . . 964

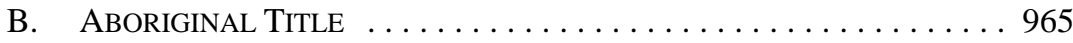

C. TREATY AND ABORiginal RightS to Hunt, FISH, AND TRAP . . . . . . . . . . . . . . . . . 967

IV. THE AbORiginAl Rights APPROACH $\ldots \ldots \ldots \ldots \ldots \ldots \ldots . \ldots . \ldots 93$

* Assistant Professor, Environmental Law Group, University of Ottawa, Faculty of Law, Common Law Section.

Graduated from the University of Ottawa, Faculty of Law, Common Law Section in 2009 and is currently articling in British Columbia. The authors are grateful for the input of Professor Gordon Christie of the University of British Columbia, and Professors Bradford Morse and Stewart Elgie of the University of Ottawa. 


\section{OBLIGATIONS FlOWING FROM AN IMPLICIT \\ RIGHT TO CONSERVATION . . . . . . . . . . . . . . . . . . . . . . . . 986 \\ VI. EXTINGUISHMENT AND JUSTIFIABLE INFRINGEMENT . . . . . . . . . . . . . 987

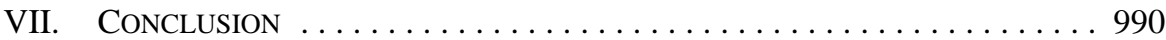

\section{INTRODUCTION}

The idea that Aboriginal peoples ${ }^{1}$ have unique environmental rights by virtue of their Indigenous status is not a novel one. Indeed, the concept of Indigenous environmental rights has received considerable academic attention. ${ }^{2}$ The environmental rights of Aboriginal peoples have also been recognized in international human rights documents. Article 29(1) of the United Nations Declaration on the Rights of Indigenous Peoples, for example, declares that

[i]ndigenous peoples have the right to the conservation and protection of the environment and the productive capacity of their lands or territories and resources. States shall establish and implement assistance programmes for indigenous peoples for such conservation and protection, without discrimination. ${ }^{3}$

The environmental interests of Indigenous peoples require special attention for two reasons. ${ }^{4}$ First, Indigenous peoples enjoy a unique relationship with their traditional territories. In many cases, members of Aboriginal communities engage in subsistence and/or commercial resource activities such as hunting, fishing, and trapping, which place them in a direct relationship of dependence on land and resources. ${ }^{5}$ Moreover, connection with and stewardship of the land is a central organizing principle in Aboriginal socio-legal, spiritual, and political systems. ${ }^{6}$ As one commentator has written, “[t]he First Nations’ relationships

Constitution Act, 1982, being Schedule B to the Canada Act 1982 (U.K.), 1982, c. 11, s. 35(2) [Constitution], defines Aboriginal peoples to include the "Indian, Inuit and Métis peoples of Canada." We will use the term "Aboriginal" interchangeably with the term "Indigenous," which is more commonly used in the international literature: see e.g. Erica-Irene A. Daes, "The Concepts of SelfDetermination and Autonomy of Indigenous Peoples in the Draft United Nations Declaration on the Rights of Indigenous Peoples” (2001) 14 St. Thomas L. Rev. 259. See also Bradford W. Morse, “Aboriginal and Treaty Rights in Canada” (2005) 27 Sup. Ct. L. Rev. (2d) 499 at 577-81.

2 See e.g. Robert K. Hitchcock, "International Human Rights, the Environment, and Indigenous Peoples" (1994) 5 Colo. J. Int'l Envtl. L. \& Pol’y 1; Benjamin J. Richardson, “The Ties That Bind: Indigenous Peoples and Environmental Governance” in Benjamin J. Richardson, Shin Imai \& Kent McNeil, eds., Indigenous Peoples and the Law: Comparative and Critical Perspectives (Oxford: Hart Publishing, 2009) 337; William Andrew Shutkin, "International Human Rights Law and the Earth: The Protection of Indigenous Peoples and the Environment” (1991) 31 Va. J. Int’l L. 479; Laura Westra, Environmental Justice and the Rights of Indigenous Peoples (London: Earthscan, 2008).

3 United Nations Declaration on the Rights of Indigenous Peoples, UN GAOR, 61st Sess., UN Doc. A/RES/61/295 (2007). Unfortunately, Canada was one of a small minority of states (including Australia, New Zealand, and the United States) that voted against the Declaration. One hundred and forty-four nations voted in favour of the Declaration, demonstrating that the international community supports the conservation and protection of lands used by Indigenous persons.

4 See generally Cherie Metcalf, "Indigenous Rights and the Environment: Evolving International Law" (2003-2004) 35 Ottawa L. Rev. 101; Bradford Morse, "Indigenous Rights as a Mechanism to Promote Environmental Sustainability” in Laura Westra, Klaus Bosselmann \& Richard Westra, eds., Reconciling Human Existence with Ecological Integrity: Science, Ethics, Economics and Law (London: Earthscan, 2008) 159; Westra, supra note 2.

$5 \quad$ See John Borrows, "Living Between Water and Rocks: First Nations, Environmental Planning and Democracy” (1997) 47 U.T.L.J. 417 [Borrows, “Living Between Water and Rocks”].

6 The Supreme Court of Canada has recognized the importance of the connection between Indigenous peoples and their land and territories. Morse, supra note 4 at 161, cites the unanimous judgement in Haida Nation v. British Columbia (Minister of Forests), 2004 SCC 73, [2004] 3 S.C.R. 511 [Haida], in which the Court wrote that the cedar forest in question "remains central to [the Haida's] life and their conception of themselves" (para. 2). 
with the land have always defined their identity, their spiritual ecology and their reality."” In stark contrast to Western world views which commodify land and define its worth according to human use-value, Indigenous belief systems traditionally recognize inherent "value in the world, and in relationships properly maintained with the land."

Second, Indigenous peoples in Canada (and around the globe) ${ }^{9}$ bear a disproportionate share of environmental burdens compared to their non-Indigenous counterparts, a trend that has been described as environmental racism. ${ }^{10}$ Aboriginal peoples in Canada are particularly affected by unsustainable forestry practices, ${ }^{11}$ climate change (resulting in serious disruption to arctic ecosystems), ${ }^{12}$ large-scale hydroelectric projects, ${ }^{13}$ low-level flight testing, ${ }^{14}$ destructive extractive projects, ${ }^{15}$ contaminated drinking water, ${ }^{16}$ indoor air pollution, ${ }^{17}$ and,

James Sakej Youngblood Henderson, “Empowering Treaty Federalism” (1994) 58 Sask. L. Rev. 241 at 263. See also Michael Coyle, "Addressing Aboriginal Land Rights in Ontario: An Analysis of Past Policies and Options for the Future - Part I” (2005) 31 Queen’s L.J. 75 at 81; Westra, supra note 2 at 126.

Gordon Christie, “A Colonial Reading of Recent Jurisprudence: Sparrow, Delgamuukw and Haida Nation" (2005) 23 Windsor Y.B. Access Just. 17 at 50.

9 For numerous examples, see Neil A.F. Popovic, "In Pursuit of Environmental Human Rights: Commentary on the Draft Declaration of Principles on Human Rights and the Environment” (1996) 27 Colum. H.R.L. Rev. 487.

$10 \quad$ Westra, supra note 2 at $135-57$

11 Consider, for example, the clear-cutting of traditional hunting and trapping areas: see e.g. Amnesty International, "Grassy Narrows: Overview," online: Amnesty International <http://www.amnesty.ca/ themes/indigenous_grassy_narrows.php>. Also note that populations that consume wild game are disproportionately exposed to forestry herbicides not intended for human consumption: see generally National Aboriginal Forestry Association, "A Petition to Prevent the Commercial Application of Nonessential Herbicides (a type of pesticide intended to kill plants) in Northern Ontario," online: National Aboriginal Forestry Association <http://www.nafaforestry.org/documents/NAFApetition2c.pdf>.

12 In 2005, the Inuit Circumpolar Council petitioned the Inter-American Commission on Human Rights (IACHR) alleging that global warming caused by greenhouse gases was infringing Inuit peoples' human rights: see Inuit Circumpolar Council (Canada), Press Release, "Inuit Petition Inter-American Commission on Human Rights to Oppose Climate Change Caused by the United States of America” ( 7 December 2005), online: Inuit Circumpolar Council <http://www.inuitcircumpolar.com/index.php? Lang=En\&ID=316>. In early 2007, the IACHR held a hearing on the topic but has yet to release a public statement or decision: see Earthjustice, Press Release,"Inter-American Commission on Human Rights to Hold Hearing on Global Warming” (6 February 2007), online: Earthjustice <http://www.earthjustice. org/news/press/007/inter-american-commission-on-human-rights-Hearing-on-Global-Warming.html>.

13 Letter from Alex Neve to Dalton McGuinty (16 April 2007) "Respect the Rights of the People of Grassy Narrows: Open Letter to Ontario Premier Dalton McGuinty," online: Amnesty International <http:// www.amnesty.ca/grassy_narrows/open_letter.php>.

14 Environmental Defence, "History of Environmental Defence," online: Environmental Defence <http:// www.environmentaldefence.ca/campaigns/history.htm>.

15 For example, unusually high rates of cancer and immune system diseases among members of the Athabasca Chipewyan First Nation community in Alberta has led many to speculate that serious health problems are caused by environmental contamination from upstream tarsands projects: see “"Comprehensive' review of Fort Chipewyan cancer rates announced” CBC News (22 May 2008), online: CBC News <http://www.cbc.ca/canada/edmonton/story/2008/05/22/edm-fort-chip.html>. Aboriginal communities in Canada have also expressed concern over uranium mining and exploration in their traditional territories: see e.g. MiningWatch Canada, "Algonquins Demanding Moratorium on Uranium Exploration on Traditional Territory” (31 August 2007), online: MiningWatch Canada $<$ http://www. miningwatch.ca/en/algonquins-demanding-moratorium-uranium-exploration-traditionalterritory>.

16 Office of the Auditor General, Report of the Commissioner of the Environment and Sustainable Development to the House of Commons, Chapter 5: Drinking Water in First Nations Communities (Ottawa: Office of the Auditor General of Canada, 2005).

17 For example, mold in First Nations houses has been a serious and widespread health issue, leading to the 2006 National Mold Strategy developed jointly by the Assembly of First Nations, Indian and Northern Affairs Canada, Health Canada, and the Canadian Mortgage and Housing Corporation: see Assembly of First Nations, "Housing," online: Assembly of First Nations <http://www.afn.ca/article. asp?id=105> . 
in some cases, industrial contamination. ${ }^{18}$ Given the unique relationship between Aboriginal peoples and their lands coupled with the documented prevalence of disproportionate environmental harm among these communities, there is a clear need to entrench Aboriginal environmental rights in Canadian jurisprudence.

In this article, we address one possible source of Aboriginal environmental rights in the Canadian legal order. We argue that Aboriginal peoples in Canada enjoy a right to conservation ${ }^{19}$ under s. 35 of the Constitution as an incident to constitutionally guaranteed treaty and Aboriginal rights to hunt, fish, and trap.

In Part II, we briefly review existing and possible legal protections for Indigenous environmental rights in Canadian public and private law, including environmental statutes, the Canadian Charter of Rights and Freedoms,$^{20}$ and tort law mechanisms. In Part III, we canvass Aboriginal law sources of Indigenous environmental rights, including the Crown's fiduciary duty to Aboriginal people and Aboriginal title. In this Part we focus, in particular, on treaty and Aboriginal rights to hunt, fish, and trap, and argue in favour of an implicit treaty right to environmental preservation. In Part IV, we review how an implicit right to conservation may be founded in Aboriginal rights in the absence of treaty guarantees. In Part $\mathrm{V}$, we examine the legal obligations that flow from an implicit right to conservation. Finally, in Part VI, we discuss the extinguishment of Aboriginal and treaty rights and the question of justifiable infringement by the Crown. We conclude that there is substantial support for an implicit right to conservation in Aboriginal and treaty rights to hunt, fish, and trap that, at the very least, prohibits environmental harm which is serious enough to threaten the life, health, or cultural survival of Aboriginal peoples.

\section{Protections for Indigenous ENVIRONMENTAL RIGHTS IN CANADIAN LAW}

In the domestic sphere, there are a number of avenues available to Aboriginal peoples who wish to protect their traditional territories from environmental degradation. First, federal and provincial environmental statutes should theoretically be available to protect Aboriginal peoples' lands and resources. Unfortunately, Canadian environmental legislation has largely failed Aboriginal peoples both in substance and process. Substantively, our environmental law regime has failed to protect environmental integrity in Aboriginal territories and

18 For example, the Aamjiwnaang First Nation near Sarnia, Ontario is the only community in the world where the female-to-male birth ratio has reached two-to-one, a phenomenon that is believed to be related to extensive pollution from nearby industrial chemical plants: see Constanze A. Mackenzie, Ada Lockridge \& Margaret Keith, "Declining Sex Ratio in a First Nation Community" (2005) 113 Environmental Health Perspectives 1295.

19 Throughout this article, we argue in favour of a right to conservation, which we understand to be a level of environmental preservation sufficient to support adequate stocks of prey animal/fish populations. The conservation ethos, focusing as it does on the management of discrete, commodified, "natural resources," is arguably a Eurocentric one. Recognizing the multiplicity of cultural and theoretical approaches to environmental protection, and the pressing need to integrate Aboriginal perspectives into environmental regulation at all levels, we have nonetheless chosen to focus on the concept of conservation for one main reason: conservation is a concept that is both understood and valued by the Canadian judiciary, and is thus the most promising avenue for initiating the entrenchment of environmental rights within s. 35. Since governments can justify the infringement of s. 35 rights on the basis of conservation objectives, the claim that Aboriginal peoples themselves ought to be able to rely on a similar argument in favour of conservation ought to resonate with courts.

20 Part I of the Constitution Act, 1982, being Schedule B to the Canada Act 1982 (U.K.), 1982, c. 11 [Charter]. 
beyond. ${ }^{21}$ Procedurally, Canadian environmental regulation has historically excluded Aboriginal peoples from meaningful participation in decision-making processes. ${ }^{22}$ Under both federal and provincial environmental legislation, critical decisions involving the balancing of environmental harm with other interests have been left to governmental decision-makers, often to the detriment of Aboriginal peoples. ${ }^{23}$

The situation has improved somewhat since the specific inclusion of Aboriginal interests in environmental assessment legislation both provincially and at the federal level. ${ }^{24}$ The federal government has made some efforts to enhance Aboriginal participation in environmental assessments involving their traditional lands and resources. ${ }^{25}$ At the policy level, environmental regulators have also increased efforts to integrate Aboriginal traditional knowledge into environmental decision-making. ${ }^{26}$ However, neither traditional knowledge policy nor environmental assessment statutes enfranchise Aboriginal peoples (nor the public generally) in the final decision-making process. When the policy exercise or environmental assessment is complete, it is open to the government to decide, for example, that harm to Aboriginal hunting grounds is outweighed by the economic benefit of building a new road. Thus, environmental legislation and policy provide inadequate protection for Aboriginal environmental rights in Canada.

Beyond the realm of ordinary statute law, Aboriginal peoples may also seek recourse to the Charter in order to protect their environments. Where environmental harm threatens life

See generally David R. Boyd, Unnatural Law: Rethinking Canadian Environmental Law and Policy (Vancouver: UBC Press, 2003); Pollution Watch, Shattering the Myth of Pollution Progress in Canada: A National Report (Toronto: Canadian Environmental Law Association, 2004); Canada, Office of the Auditor General, Report of the Commissioner of the Environment and Sustainable Development to the House of Commons, Chapter 1: International Environmental Agreements (Ottawa: Office of the Auditor General of Canada, 2004).

22 See Borrows, "Living Between Water and Rocks," supra note 5 at 418-20 [footnotes omitted]:

[Aboriginal peoples] exist just beyond the borders of the North American legal imagination. In land use planning processes they are caught between the peripheries of competing political jurisdictions. The relationships of federalism have been more attentive to national and provincial interests and thus constricted the political space within which [Aboriginal nations operate]. The community has little or no opportunity to influence environmental ideas, design, and decision making. Towering behind them are the escarpment-like barriers and constraints of a racist and outdated Indian Act. This archaic federal document casts long, dark shadows across First Nations' governmental powers. Participation in environmental planning is hindered by the Indian Act because it limits the steps Indigenous peoples could take to more directly address environmental challenges. Compressing First Nations from the other side are the deep waters of provincial authority. Indigenous peoples are often submerged and invisible in their own land because the province does not make provision for a representation of their interests. These federalist structures organize, separate, and allocate water and rocks in a manner which promotes unequal distributions of political influence. A 'legal geography of space' is thus constructed which marginalizes Indigenous peoples in significant environmental decision making. See ibid.

24 See e.g. Canadian Environmental Assessment Act, S.C. 1992, c. 37, s. 2(1), defining the "environmental effects" which must be considered in every screening report as including "any change that the project may cause in the environment, including any change it may cause to ... the current use of lands and resources for traditional purposes by aboriginal persons." It has been held that failure to address established Aboriginal interests in the course of an environmental assessment is an error of law: see Union of Nova Scotia Indians v. Canada (Attorney General) (1996), 122 F.T.R. 81.

25 These include translation of environmental assessments into Aboriginal languages, inclusion of Aboriginal members on assessment panels (including a federal-provincial environmental assessment of a proposed transmission line in northern Manitoba in which a majority of panel members were Aboriginal), and express consideration of traditional Aboriginal knowledge in the terms of reference of panel reviews: see Rodney Northey \& William A. Tilleman, “Environmental Assessment” in Elaine L. Hughes, Alastair R. Lucas \& William A. Tilleman, eds., Environmental Law and Policy, 2d ed. (Toronto: Emond Montgomery Publications, 1998) at 189.

26 Environment Canada, “Aboriginal Traditional Knowledge and Environmental Management” (2002) 32 Science and the Environment Bulletin 1. 
or health, Aboriginal groups or individuals may seek redress by invoking their s. 7 rights to life and security of person. ${ }^{27}$ Where the land in issue has spiritual significance, the First Nation may argue that environmental degradation or destruction of the land would violate its freedom of religion, protected under s. 2(a) of the Charter, but this argument has yet to be accepted in Canada. ${ }^{28}$ Similarly, the viability of environmental claims under s. 7 remains unsettled, despite a small body of case law and scholarship suggesting the validity of such claims. ${ }^{29}$ Thus, the probability of success in using the Charter to protect Aboriginal environmental rights is unclear at this time.

Where public law mechanisms fail, private law remedies may also be available to protect Indigenous environmental rights. ${ }^{30}$ Aboriginal individuals and groups may invoke private law causes of action (particularly the torts of nuisance, trespass, and the rule in Rylands $v$. Fletcher $^{31}$ ) to address environmental contamination in their territories. This is a promising avenue for future litigation but does not adequately represent the nation-to-nation relationship between Aboriginal peoples and Canada. Despite its significant limitations, Aboriginal law in Canada, and particularly the law of s. 35 of the Constitution, is an appropriate locus for reconciliation between Aboriginal peoples and the rest of Canadian society.

The remainder of this article will analyze the various Aboriginal law mechanisms for protecting Indigenous environmental rights in Canada, with a focus on Aboriginal and treaty rights to hunt, fish, and trap.

\section{Aboriginal Law Sources of INDIGENOUS ENVIRONMENTAL RIGHTS IN CANADA}

\section{A. THE CROWN's FiduCIARY DUTY}

One possible source of environmental rights for Aboriginal peoples in Canada is the Crown's fiduciary duty. It is well established that the Crown is under a fiduciary duty in its relations with Aboriginal peoples ${ }^{32}$ and that this duty is independent of the constitutional guarantees provided in s. $35 .{ }^{33}$ Although analysis of the Crown's fiduciary duty to Aboriginal peoples has largely focused on the justificatory analysis of infringements of s. 35, the fiduciary duty in fact pre-dates s. 35 and is an overarching obligation imposed on the Crown

See Lynda M. Collins, “An Ecologically Literate Reading of the Canadian Charter of Rights and Freedoms” (2009) 26 Windsor Rev. Legal Soc. Issues 7 [Collins, "Ecologically Literate Reading of the Charter"]. For a successful example of such a claim at the international level, see the Yanomami Case (1985), Inter-Am. Comm. H.R. No. 12/85 at 24; Annual Report of the Inter-American Commission on Human Rights: 1984-1985, OEA/Ser.L/V/ II.66/doc.10, rev. 1.

28 See generally John Borrows, "Living Law on a Living Earth: Aboriginal Religion, Law, and the Constitution” in Richard Moon, ed., Law and Religious Pluralism in Canada (Vancouver: UBC Press, 2008) 161. For an unsuccessful attempt to make a s. 2(a) claim for environmental protection of spiritually significant First Nations traditional territory, see Kelly Lake Cree Nation v. British Columbia (Ministry of Energy and Mines) (1998), [1999] 3 C.N.L.R. 126 (B.C.S.C.).

$29 \quad$ Collins, "Ecologically Literate Reading of the Charter," supra note 27; Morse, supra note 4.

30 See Lynda M. Collins, "Protecting Aboriginal Environments: A Tort Law Approach” in Sandra Rodgers, Rakhi Ruparelia \& Louise Bélanger-Hardy, eds., Critical Torts (Markham, Ont.: LexisNexis, 2009) 61. [1868] 3 L.R.H.L. 330.

Guerin v. The Queen, [1984] 2 S.C.R. 335 [Guerin]; R. v. Sparrow, [1990] 1 S.C.R. 1075 [Sparrow]. Guerin, ibid.; Sparrow, ibid.; R. v. Van der Peet, [1996] 2 S.C.R. 507 [Van der Peet]. 
in all of its dealings with Aboriginal peoples. ${ }^{34}$ While a detailed analysis of fiduciary law as a tool for protecting the environmental rights of Aboriginal peoples will be left to other writers, the general premise of the argument for a fiduciary duty to protect First Nations' environments appears to be straightforward.

Since environmental degradation of their traditional territories without their consent is frequently adverse to First Nations' interests, it will often be arguable that when the Crown authorizes environmentally destructive activities on First Nations' land, it has breached its fiduciary duty. The argument is particularly compelling in situations in which the environmental harm threatens the physical and/or cultural integrity of the First Nation. ${ }^{35}$ However, it should be equally applicable in situations in which the unconsented-to degradation threatens First Nations' economic welfare. ${ }^{36}$ Grounding claims to Aboriginal environmental rights in the Crown's free-standing fiduciary duty has the benefit of tying those rights to an ongoing obligation. As Laura Westra has written: “[ $t$ ] he Crown's fiduciary duty is not a temporary contract... nor is the duty owed only to one or another nation. That duty, by its very nature, demands respect for the integrity of the land, in perpetuity." ${ }^{\text {"T }}$ The free-standing fiduciary duty is relatively underdeveloped in the Aboriginal law jurisprudence and should provide fertile ground for future research.

\section{B. Aboriginal Title}

Aboriginal title, a subset of Aboriginal rights (which will be discussed in greater detail in Part IV, below) may also be invoked to protect Aboriginal peoples' environments. Aboriginal title may exist where an Aboriginal group can prove that it had exclusive occupation of the claimed land at the time of the Crown's assertion of sovereignty. ${ }^{38}$ If present occupation of the land is relied upon as proof of pre-sovereignty occupation, there must be an element of continuity in the group's occupation of the claimed land. ${ }^{39}$ There are signs that the approach to recognizing Aboriginal title in the courts may not yet be fixed. In a concurring judgment in Marshall-Bernard, ${ }^{40}$ LeBel J. took the opportunity to challenge the current strict test for Aboriginal title. In particular, he noted that the current focus on occupation to prove possession is imbued with Western notions of land use and does not adequately reflect Aboriginal relationships to land. Most importantly, he wrote:

If aboriginal title is a right derived from the historical occupation and possession of land by aboriginal peoples, then notions and principles of ownership cannot be framed exclusively by reference to common law

See e.g. Guerin, ibid, at 336, in which the Supreme Court of Canada found that the Crown's fiduciary duty exists because Parliament has conferred upon the Crown the obligation to act in the best interests of Aboriginal peoples. The duty exists independently of any statutory provisions. Section 35 of the Constitution, supra note 1 , was not at issue in the case.

35 This would be the case where, for example, the environmental harm constitutes a health threat, is inconsistent with necessary subsistence activities, or disrupts culturally or spiritually significant practices.

36 Hypothetical examples could include water pollution forcing the closure of a First Nations' bottled water enterprise, or clear-cutting destroying a commercial trapping operation.

Westra, supra note 2 at 134.

Delgamuukw v. British Columbia, [1997] 3 S.C.R. 1010 at para. 143 [Delgamuukw].

See generally Brian J. Burke, "Left Out in the Cold: The Problem with Aboriginal Title Under Section 35(1) of the Constitution Act, 1982 for Historically Nomadic Aboriginal Peoples” (2000) 38 Osgoode Hall L.J. 1.

$40 \quad$ R. v. Marshall; R. v. Bernard, 2005 SCC 43, [2005] 2 S.C.R. 220 [Marshall-Bernard]. The main issue in Marshall-Bernard was whether the First Nation's treaty rights extended to logging on Crown land; the Supreme Court found that it did not. 
concepts. The patterns and nature of aboriginal occupation of land should inform the standard necessary to prove aboriginal title. The common law notion that "physical occupation is proof of possession" remains, but the nature of the occupation is shaped by the aboriginal perspective, which includes a history of nomadic or semi-nomadic modes of occupation. ${ }^{41}$

\begin{abstract}
The nature and patterns of land use that are capable of giving rise to a claim for title are not uniform and are potentially as diverse as the aboriginal peoples that possessed the land prior to the assertion of Crown sovereignty. The fact that a tract of land was used for hunting instead of agriculture does not mean that the group did not possess the land in such a way as to acquire aboriginal title. Taking into account the aboriginal perspective on the occupation of land means that physical occupation as understood by the modern common law is not the governing criterion. The group's relationship with the land is paramount. To impose rigid concepts and criteria is to ignore aboriginal social and cultural practices that may reflect the significance of the land to the group seeking title. The mere fact that the group travelled within its territory and did not cultivate the land should not take away from its title claim. ${ }^{42}$
\end{abstract}

Given historic land use patterns, LeBel J.'s critique of the current test for Aboriginal title would strengthen claims for Aboriginal title. If adopted by the courts, his approach could serve to ground claims to Aboriginal title based, in part, on evidence of historic patterns of natural resource management and stewardship.

With respect to content, the Supreme Court has held that Aboriginal title encompasses the right to exclusive use and possession of the land, subject only to the qualification that Aboriginal title lands may not be subjected to any use that is "irreconcilable with the nature of the attachment to the land which forms the basis of the particular group's aboriginal title." ${ }^{43}$ On its face, this articulation of the doctrine empowers holders of Aboriginal title to prevent environmental degradation (and any other unwanted activities) on their lands. Furthermore, this definition of Aboriginal title raises the possibility of obtaining an interlocutory injunction against environmentally destructive activity on lands which are subject to a claim to Aboriginal title. ${ }^{44}$

There are two major barriers to the effective use of Aboriginal title as a mechanism for protecting Indigenous environmental rights. First (and perhaps most importantly), proving Aboriginal title is notoriously time-consuming, resource-intensive, and difficult. Indeed, at the time of writing, no First Nation in Canada had yet succeeded in a claim of Aboriginal

Ibid. at para. 131.

Ibid. at para. 136.

Delgamuukw, supra note 38 at para. 111.

In Haida, supra note 6, the Haida claimed Aboriginal title to the lands in question and sought an interlocutory injunction to prevent logging of the area while their title claim was being proved. The Supreme Court of Canada held that it was open to litigants to seek interlocutory injunctions in the context of unproven claims for title, but also held that they are not limited to injunctive remedies and imposed the additional duty to consult on the Crown (paras. 12-15). 
title. ${ }^{45}$ Second, as with Aboriginal rights, the breadth of permitted infringements poses a real challenge in mobilizing Aboriginal title as a vehicle for environmental protection. ${ }^{46}$

\section{Treaty And Aboriginal Rights to Hunt, Fish, AND Trap}

Another possible source of Aboriginal environmental rights in Canada, and the focus of the present analysis, is the treaty or Aboriginal rights to hunt, fish, and trap. Much of the case law dealing with treaty and Aboriginal rights to hunt, fish, and trap has arisen in the context of conflict between those activities and government regulation purportedly enacted for conservation purposes. ${ }^{47}$ However, these same resource rights could potentially be invoked by Aboriginal peoples in order to protect their environments. Protecting lands and territories in the context of rights to harvest resources will be particularly important to First Nations that practise some form of sustainable resource use and whose lands or resources are threatened with depletion and/or pollution.

The existence of an unextinguished treaty or Aboriginal right to environmental protection entails a corresponding constitutional duty on the part of the government to justify any infringement of such right according to the test laid out in Sparrow, outlined in Part VI, below. Laws or other government actions that infringe a treaty right to environmental protection and cannot be justified are of no force or effect. ${ }^{48}$

As the following analysis will demonstrate, there is a strong argument that many, if not most, of the treaties concluded with First Nations in Canada encompass a right to environmental preservation in surrendered lands sufficient to support ongoing subsistence activities, including hunting, fishing, and trapping. The argument for treaty rights to conservation of resources to support subsistence-based lifestyles arises from basic principles of treaty interpretation as applied to the specific histories of treaty-making in Canada. While

45 After years of litigation, the Court in Xeni Gwet'in First Nations v. British Columbia, 2007 BCSC 1700, [2008] 1 C.N.L.R. 112, found that the First Nation had adequately demonstrated Aboriginal title to a portion of the lands claimed, but declined to issue a declaration of title because the claim had been framed in an "all-or-nothing" fashion. Having found an adequate evidentiary claim to Aboriginal title to a portion of the lands, and having issued a declaration of the First Nation's Aboriginal rights in the area, the Court admonished the parties to resolve their dispute through negotiation. While discussions are ongoing, so far negotiations have been unsuccessful and the British Columbia Court of Appeal has granted leave to appeal: see Xeni Gwet'in First Nations v. British Columbia, 2009 BCCA 83, [2009] 2 C.N.L.R. 385.

46 Delgamuukw, supra note 38. For example, at para. 165, Lamer C.J.C. suggested that valid objectives that could justify infringement on Aboriginal title might include “development of agriculture, forestry, mining, and hydroelectric power, ... protection of the environment or endangered species, the building of infrastructure and the settlement of foreign populations to support those aims." Kent McNeil has argued persuasively that Lamer's list of examples, and the way it has been used by courts since Delgamuukw, demonstrates that the concept of reconciliation between Canadian society, as a whole, and Aboriginal peoples can be used to justify “almost any kind of infringement of Aboriginal title”: see Kent McNeil, "Reconciliation and the Supreme Court: The Opposing Views of Chief Justices Lamer and McLachlin” (2003) 2 Indigenous L.J. 1 at 20. See also André Goldenberg, “'Surely Uncontroversial”: The Problems and Politics of Environmental Conservation as a Justification for the Infringement of Aboriginal Rights in Canada” (2002) 1 J.L. \& Equality 278 at 281; Kent McNeil, “The Vulnerability of Indigenous Land Rights in Australia and Canada” (2004) 42 Osgoode Hall L.J. 271 at 290-91. See e.g. R. v. Taylor (1981), 34 O.R. (2d) 360 (C.A.); R. v. Simon, [1985] 2 S.C.R. 387 [Simon]; R. v. Sioui, [1990] 1 S.C.R. 1025 [Sioui]; Sparrow, supra note 32; Canada v. Peters, 2001 BCSC 873, [2002] 1 C.N.L.R. 85; R. v. Lefthand, 2007 ABCA 206, 77 Alta. L.R. (4th) 203; R. v. Aleck, 2008 BCSC 1097, [2008] 4 C.N.L.R. 133. Goldenberg has argued that conservation is an insufficient justification for infringing Aboriginal rights and has been misapplied by the courts to justify unacceptable infringements: see Goldenberg, ibid. Sparrow, ibid. 
the phrasing of treaty guarantees to hunt, fish, and trap varied between treaties, a survey of First Nations treaties in Canada reveals that virtually all of the major treaties included such guarantees. $^{49}$

\section{APPLiCATION OF PRINCIPLES OF TREATY INTERPRETATION TO RESOURCE RIGHTS}

The Supreme Court of Canada has developed a coherent set of principles of interpretation to be applied to the construction of First Nations treaties. In Badger ${ }^{50}$ the Supreme Court summarized the principles governing treaty interpretation as follows:

First, it must be remembered that a treaty represents an exchange of solemn promises between the Crown and the various Indian nations. It is an agreement whose nature is sacred.... Second, the honour of the Crown is always at stake in its dealing with Indian people.... It is always assumed that the Crown intends to fulfil its promises. No appearance of "sharp dealing” will be sanctioned.... Third, any ambiguities or doubtful expressions in the wording of the treaty or document must be resolved in favour of the Indians. A corollary to this principle is that any limitations which restrict the rights of Indians under treaties must be narrowly construed.... Fourth, the onus of proving that a treaty or aboriginal right has been extinguished lies upon the Crown. There must be "strict proof of the fact of extinguishment" and evidence of a clear and plain intention on the part of the government to extinguish treaty rights. ${ }^{51}$

In addition, when considering a treaty, a court must take into account the context in which the treaties were negotiated, concluded and committed to writing. The treaties, as written documents, recorded an agreement that had already been reached orally and they did not always record the full extent of the oral agreement.... As a result, it is well settled that the words in the treaty must not be interpreted in their strict technical sense nor subjected to rigid modern rules of construction. Rather, they must be interpreted in the sense that they would naturally have been understood by the Indians at the time of the signing. ${ }^{52}$

In the case of Sundown, Cory J., for the Supreme Court quoted the passage cited above and made the following statements:

In many if not most treaty negotiations, members of the First Nations could not read or write English and relied completely on the oral promises made by the Canadian negotiators. There is a sound historical basis for interpreting treaties in the manner summarized in Badger. Anything else would amount to be a denial of fair dealing and justice between the parties. ${ }^{53}$

See Youngblood Henderson, supra note 7; Shin Imai, "Treaty Lands and Crown Obligations: The ‘Tracts Taken Up’ Provision” (2001) 27 Queen’s L.J. 1 at 5, 13-14.

R. v. Badger, [1996] 1 S.C.R. 771 [Badger].

Ibid. at para. 41 [footnotes omitted].

Ibid. at para. 52.

R. v. Sundown, [1999] 1 S.C.R. 393 at para. 24 [Sundown]. 
If any doubt remained regarding the consideration to be given to oral promises in treaty interpretation, ${ }^{54}$ it was firmly put to rest by the decision of the Supreme Court in Marshall $I .{ }^{55}$ In that case, the Supreme Court found that the Nova Scotia Court of Appeal had erred in holding that extrinsic evidence could only be put to use where there were ambiguities in the written treaty. The Supreme Court went on to hold, in keeping with Guerin, that "where a treaty was concluded verbally and afterwards written up by representatives of the Crown, it would be unconscionable for the Crown to ignore the oral terms while relying on the written terms."56

Thus, based on Badger and Marshall I, there is a strong argument that only those promises which were agreed to orally by a First Nation can be treated as terms of the treaty. Certainly, oral promises made by Crown negotiators should be given considerable weight when interpreting the terms of a treaty. This approach is consistent with the general fiduciary duty of the Crown towards Aboriginal peoples first established in Guerin and constitutionalized in Sparrow. In fact, this approach was in use by some Canadian courts years before these landmark decisions.

In Paulette, ${ }^{57}$ having found that the Aboriginal signatories had been reassured in the course of treaty negotiations that their land rights would not be interfered with, the trial judge held that

Treaty 8 and Treaty 11 could not legally terminate Indian land rights. The Indian people did not understand or agree-to the terms appearing in the written version of the treaties, only the mutually understood promises relating to wild life, annuities, relief and friendship became legally effective committments. ${ }^{58}$

Patrick Macklem argues that "[a]n expansive interpretation of the right to hunt, trap, and fish would be consonant with the legal principles of treaty interpretation" established by the Supreme Court of Canada. ${ }^{59}$ The principle that the treaty is to be interpreted in the sense that it would naturally have been understood by the Aboriginal people at the time of signing compels a conclusion that treaty rights to harvest resources encompass a right to conservation of such resources at a level which permits meaningful subsistence. Similarly, both the concern with upholding the honour of the Crown and the principle that limitations on First Nations' rights must be narrowly read militate in favor of the argument for an implicit right to conservation. When the basic principles of treaty interpretation established by the Supreme Court are applied to treaty guarantees of hunting, fishing, and trapping rights, it is clear that these guarantees should be read as encompassing a right to conservation of the resources which support these activities.

The doubts arise primarily from the Supreme Court's 1988 decision in $R v$. Horse [1988]1 S.C.R. 187 at paras. 35, 50, in which the Court held that "extrinsic" evidence could be used only to clarify ambiguities in the written treaties.

R. v. Marshall, [1999] 3 S.C.R. 456 [Marshall I].

Ibid. at para. 12 .

Paulette v. Canada (Registrar of Titles) (No. 2) (1973), 42 D.L.R. (3d) 8 (N.W.T.S.C.) [Paulette].

Ibid. at 30.

Patrick Macklem, “The Impact of Treaty 9 on Natural Resource Development in Northern Ontario” in Michael Asch, ed., Aboriginal and Treaty Rights in Canada: Essays on Law, Equality, and Respect for Difference (Vancouver: UBC Press, 1997) 97 at 116. 
The logical argument for an implied treaty right to conservation is analogous to the self-evident proposition that a substantive right to eat must include a right to food. In order to give meaning to treaty rights to harvest resources, an implied right to conservation must be acknowledged. Randy Kapashesit and Murray Klippenstein assert that

[a] group right to conduct a particular activity (such as hunting, fishing and trapping) is meaningless when the object of that right (the deer stock and the deer's habitat, the fish stock and the fish habitat) is subject to damage or depletion by external individuals or groups, unless the group has some means to protect that stock or habitat from those external factors. ${ }^{60}$

Similarly, in $R$. v. Nikal ${ }^{61}$ (in the context of deciding whether fishery licensing requirements violated Aboriginal rights) Cory J. observed that if the government were prevented from enacting an effective conservation scheme then "[t]he very right to fish would in time become meaningless." 62 Setting aside for the moment the specific historical evidence surrounding treaty-making in Canada, it seems clear that, when they secured resource rights as a condition to the surrender of lands which had supported them since time immemorial, Aboriginal signatories to treaties could not have intended to contract for “meaningless” rights.

In Simon, Dickson C.J.C. observed "that the right to hunt to be effective must embody those activities reasonably incidental to the act of hunting itself." ${ }^{63}$ Based on this proposition, the Court found that those activities which were reasonably incidental to the act of hunting were protected under the Aboriginal right to hunt. Although one could argue that conservation is "reasonably incidental" to resource harvesting, this argument is unlikely to succeed as both Simon and Sundown demonstrate that the "reasonably incidental" test pertains to the manner in which the right is exercised. However, Simon and Sundown remain highly significant as they demonstrate that treaty rights should be interpreted in such a way as to render them "effective." Clearly, treaty rights to hunt, fish, and trap must, to be effective, encompass a right to conservation of the environment on which these activities depend.

Reviewing the treatment of resource rights in First Nations treaties in Canada, James Sakej Youngblood Henderson emphasizes the necessity of securing these rights in order to ensure First Nations’ cultural and physical survival:

[I]n the Georgian treaties the imperial Crown granted the Eastern tribes the "free liberty" of hunting and fishing as usual (that is a royal franchise under prerogative law). Additionally, the Crown promised non-interference by the British settlements and governments in the exercise of that liberty. Beginning with Treaty 3, the Crown explicitly guaranteed Aboriginal liberties to hunt and fish on lands within the ceded area. These liberties enabled them to use resources of the land and waters as a mean of maintaining ancient self-sufficiency. These liberties were as necessary to their existence as was the atmosphere they breathed. ${ }^{64}$ (1991) 36 McGill L.J. 925 at 957.

[1996] 1 S.C.R. 1013.

Ibid. at para. 94.

Simon, supra note 47 at para. 31 .

Youngblood Henderson, supra note 7 at 266 [footnotes omitted, emphasis added]. 
The necessity of resource based activities to the survival of First Nations leads inexorably to the conclusion that Aboriginal peoples would never have accepted empty abstract resource rights in exchange for ceding title to their lands. Thus, in order to reflect the Aboriginal understanding of resource rights contained in the treaties, these rights must be seen as encompassing a right to conservation of the resources at issue. The specific histories of treaty-making in Canada, particularly with respect to assurances given to Aboriginal peoples by Crown negotiators, support this contention.

\section{HISTORICAL EVIDENCE REGARDING THE MEANING OF THE TREATY GUARANTEES}

In addition to the strong theoretical argument that treaty rights to hunt, fish, and trap must include a corresponding right to conservation, there is ample historical evidence indicating that this reading is in keeping with the intent of the parties at the time most First Nations treaties were signed. Based on its comprehensive research into the history of treaty-making in Canada, the Royal Commission on Aboriginal Peoples concludes that:

First Nations would not consider making a treaty unless their way of life was protected and preserved. This meant the continuing use of their lands and natural resources. In most, if not all the treaties, the Crown promised not to interfere with their way of life, including their hunting, fishing, trapping and gathering practices .

First Nations [shared their lands] on the condition that they would retain adequate land and resources to ensure the well-being of their nations. ${ }^{65}$

In Marshall I, the Supreme Court of Canada recognized the protection of traditional First Nations economies as an animating force behind a number of First Nations treaties. Having reviewed the historical evidence regarding Mi’kmaq-British peace treaties in detail, Binnie J. explained:

Peace was bound up with the ability of the Mi'kmaq people to sustain themselves economically. Starvation breeds discontent... [Thus], it became necessary to protect the traditional Mi'kmaq economy, including hunting, gathering and fishing. A comparable policy was pursued at a later date on the west coast where, as Dickson J. commented in Jack v. The Queen, [1980] 1 S.C.R. 294, at p. 311:

What is plain from the pre-Confederation period is that the Indian fishermen were encouraged to engage in their occupation and to do so for both food and barter purposes.

The same strategy of economic aboriginal self-sufficiency was pursued across the prairies in terms of hunting: see R. v. Horseman, [1990] 1 S.C.R. 901, per Wilson J., at p. 919, and Cory J., at p. $928 .{ }^{66}$ 
Indeed, in the case of the numbered treaties, the reports of the treaty commissioners indicate that most First Nations signatories understood the treaties as a means to secure their traditional livelihood. For example, with respect to the Robinson Treaties of 1859, covering territory north of lakes Huron and Superior, Robinson made the following report to his superiors: "[b]y securing [reservations to the Indians] and the right of hunting and fishing over the ceded territory, they cannot say that the Government takes from their usual means of subsistence and therefore have no claims for support." ${ }^{\text {"7 }}$

Similarly, the Treaty 9 Commissioners reported the following in regard to negotiations respecting hunting and fishing rights:

Missabay, the recognized chief of the band, then spoke, expressing the fears of the Indians that, if they signed the treaty, they would be compelled to reside upon the reserve to be set apart for them, and would be deprived of the fishing and hunting privileges which they now enjoy.

On being informed that their fears in regard to both these matters were groundless, as their present manner of making their livelihood would in no way be interfered with, the Indians talked the matter over among themselves. ${ }^{68}$

Macklem presents strong evidence that protection and conservation of their environment and its resources was the primary motivating factor behind the Aboriginal signatories' conclusion of Treaty $9 .{ }^{69}$ Aboriginal groups had petitioned for a treaty in response to the building of the Canadian Pacific Railway line in their territory and the resulting influx of white settlers who were putting pressure on the First Nations' resources. As Visiting Superintendent of Indian Affairs James Phipps stated in 1885,

construction of the Canadian Pacific Railway has opened up the country in the neighborhood of Lake Pogamasing to White Trappers who deprive the Indians of the Beaver (which they carefully preserved, never taking all but leaving some to increase) and as the Whites kill and destroy all they can, the consequence will be that no Beaver will be left in that section of country. ${ }^{70}$

\section{In this context, Macklem concludes that}

when one begins to examine the reasons for protecting rights to hunt, fish, and trap, it becomes clear that what Aboriginal people were seeking to protect was their traditional ways of life from non-Aboriginal erosion.... As such, [Treaty 9 hunting, fishing and trapping rights] ought to be viewed as not only conferring the right to engage in the activity listed by the terms of the treaty but also including the right to expect that such activity will continue to be successful, measured by reference to the fruits of past practice. ${ }^{71}$

Alexander Morris, The Treaties of Canada with the Indians of Manitoba and the North-West Territories, Including the Negotiations on Which They Were Based, and Other Information Relating Thereto (Toronto: Belfords, Clarke \& Co., 1880) at 19 [emphasis added].

68 Letter from Duncan C. Scott, Samuel Stewart \& Daniel G. MacMartin to Superintendent General of Indian Affairs (6 November 1905), online: Indian and Northern Affairs Canada <http://www.aincinac.gc.ca/al/hts/tgu/pubs/t9/trty9-eng.asp> [emphasis added].

$69 \quad$ Macklem, supra note 59 at 117.

70 Letter from James Phipps to Superintendent General of Indian Affairs (5 February 1885), Ottawa Public Archives of Canada ( RG 10, vol. 2289, file 57, 641), cited in James Morrison, Treaty Research Report: Treaty No. 9 (1905-1906) (Ottawa: Indian and Northern Affairs Canada, 1986) at 2-3. 
Shin Imai writes that "First Nation intentions at the time the treaties were negotiated were very clear. They entered into those negotiations to preserve their way of life, not to extinguish their rights to the land and their rights to hunt, trap and fish."72 Similarly, in their comprehensive analysis of environmental rights contained in Treaty 8, Monique Ross and Cheryl Sharvit conclude that

[w] hen a generous and liberal interpretation is given to Treaty 8, and when the Aboriginal understanding and oral terms are taken into consideration, it becomes clear that the right to pursue usual vocations of hunting, trapping and fishing was in effect a guarantee that the treaty's Aboriginal signatories would be able to continue to earn a livelihood from these activities. Further, the government's ability to take up land, and thus exclude the effective exercise of treaty rights to hunt, trap and fish on such lands, was limited, and likely did not include all the purposes for which trees are harvested today. For example, clearcutting was not anticipated in 1899, nor was the scale of the logging operations which are carried out in the boreal forest. ${ }^{73}$

Ross and Sharvit cite the following passage from the dissenting judgment of Wilson J. in $R$. v. Horseman:

[I]t seems to me to be of particular significance that the Treaty 8 Commissioners, historians who have studied Treaty 8 , and Treaty 8 Indians of several different generations unanimously affirm that the government of Canada's promise that hunting, fishing and trapping rights would be protected forever was the sine qua non for obtaining the Indians' agreement to enter into Treaty 8. Hunting, fishing and trapping lay at the centre of their way of life. ${ }^{74}$

Justice Cory, for the majority, put it as follows: “The Indians wished to protect the hunting rights which they possessed before the Treaty came into effect and the federal government wished to protect the native economy which was based upon those hunting rights."75

The trial judge in Paulette reached a similar conclusion with regard to Treaties 8 and 11, stating as follows:

To me, hearing the witnesses at first hand as I did, many of whom were there at the signing, some of them having been directly involved in the treaty making, it is almost unbelievable that the Government party could have ever returned from their efforts with any impression but that they had given an assurance in perpetuity to the Indians in the territories that their traditional use of the lands was not affected. ${ }^{76}$

Finally, in Badger the Supreme Court gave significant consideration to the Treaty 8 Commissioner's Report in which the Commissioner wrote that, during treaty negotiations,

[t]here was expressed at every point the fear that the making of the treaty would be followed by the curtailment of the hunting and fishing privileges ... We pointed out ... that the same means of earning a livelihood would continue after the treaty as existed before it.

Imai, supra note 49 at 13-14 [footnotes omitted, emphasis in original].

Monique M. Ross \& Cheryl Y. Sharvit, "Forest Management in Alberta and Rights to Hunt, Trap and Fish Under Treaty 8” (1998) 36 Alta. L. Rev. 645 at 651.

[1990] 1 S.C.R. 901 at 911.

Ibid. at 928.

Paulette, supra note 57 at 33 [emphasis added]. 
Our chief difficulty was the apprehension that the hunting and fishing privileges were to be curtailed... [W]e had to solemnly assure [the Aboriginal negotiators] that only such laws as to hunting and fishing as were in the interest of the Indians and were found necessary in order to protect the fish and fur-bearing animals would be made, and that they would be as free to hunt and fish after the treaty as they would be if they never entered into it. ${ }^{77}$

Thus it is clear that what was promised to the Treaty 8 First Nations was substantive protection of their resource-based economies, which must include a right to conservation.

In Sundown, the Supreme Court considered the treaty guarantees of hunting, fishing, and trapping rights contained in Treaty 6. In negotiating that treaty, Lieutenant Governor Morris made the following statements to the Aboriginal negotiators: "You want to be at liberty to hunt as before. I told you we did not want to take that means of living from you, you have it the same as before." ${ }^{, 8}$ Treaty 6 Elder Fred Horse reports that the Treaty Commissioner said that " $[t]$ he Queen had promised that the wealth of the land would be ours.... [A]nything that the Indian uses was to be left alone. The White Man has nothing to do with it." "I9 In Sundown, Cory J., for the Court, concluded that

[i]t is clear from the history of the negotiations between Alexander Morris and the First Nations who signed Treaty No. 6 that the government intended to preserve the traditional Indian way of life. Hunting and fishing were of fundamental importance to that way of life. This was recognized in the treaty negotiations and in the treaties themselves. $^{80}$

Thus, the Court has explicitly adopted the thesis advanced above that treaty guarantees of hunting, fishing, and trapping amounted to a guarantee that the traditional Aboriginal way of life would be protected. Clearly, that way of life could not be protected without preserving the environments on which it depended, and continues to depend. Thus, treaty rights to hunt, fish, and trap, since they constitute the right to pursue the traditional Aboriginal way of life, must encompass an implied right to conservation.

It should be noted that the Court in Sundown makes a disturbing reference to "the requirement that there be compatibility between the Crown's use of the land and the treaty right claimed." 81 The Court concludes that "if the exercise of [Sundown's] hunting right were wholly incompatible with the Crown's use of the land, hunting would be disallowed and any rights in the hunting cabin [at issue] would be extinguished."82 Given that treaty rights could not be extinguished after 1982 when they were constitutionalized, this is a contentious proposition. Since the Court explicitly notes that only legislation which passes the Sparrow justificatory test could validly infringe on Treaty 6 hunting rights, it appears that it is using the "incompatibility with Crown use" test in interpreting the terms of the treaty. This

See Badger, supra note 50 at para. 39 [emphasis omitted].

Morris, supra note 67 at 218, cited in Sundown, supra note 53 at para. 5.

Sharon Venne, “Understanding Treaty 6: An Indigenous Perspective” in Michael Asch, ed., Aboriginal and Treaty Rights in Canada (Vancouver: UBC Press, 1997) 173 at 193, 196.

Sundown, supra note 53 at para. 6 [emphasis added].

Ibid. at para. 39.

Ibid. at para. 41. 
conclusion is strengthened by the decision's reference to Sioui in which the Supreme Court used the incompatibility test to interpret the scope of the Huron's treaty right to practice their religion. ${ }^{83}$

It is self-evident that conservation will often be incompatible with environmentally destructive Crown uses of land. However, to limit the content of treaty rights to those uses which are not incompatible with the Crown's use of the lands is virtually to abrogate the treaties altogether. It ignores the solemn obligations undertaken by the Crown as well as the Aboriginal understanding of treaty promises. Such an approach is wholly inconsistent with the canons of treaty interpretation developed by the Supreme Court and is clearly wrong. To date, this anomaly has not been addressed by the Court. Fortunately, the decision in Sundown was not based on the incompatibility approach, and the Court will therefore have the opportunity to clarify this issue in future cases.

\section{ANTHROPOLOGICAL EVIDENCE OF ABORIGINAL APPROACHES TO RESOURCE USE}

It is evident that every claim to an implied treaty right to conservation will have to be argued on the specific historical facts surrounding the treaty in question; however, some cautious generalizations may be made. Anthropological evidence militates in favour of a presumption that harvest rights would have been understood as including an implicit right of conservation sufficient to support such resource activities. This principle derives from cultural and spiritual principles of land stewardship, systems of sustainable resource management, ${ }^{84}$ and physical dependence on the land. ${ }^{85}$ Kapashesit and Klippenstein explain:

\footnotetext{
Care must be taken when attempting to generalize about the belief systems of hundreds of distinct Aboriginal groups in North America. However, Aboriginal environmental belief systems share a number of features.... These include a lack of division between humans and the rest of the environment, a spiritual relationship with nature, concern about sustainability, attention to reciprocity and balance, and the idiom of respect and duty (rather than rights). ${ }^{86}$
}

Thus, there would appear to be a strong argument that the notion of a mere license to exploit resources that could be depleted or destroyed by others would not have been legally cognizable in many, if not most, First Nations in Canada. ${ }^{87}$ Rather, Aboriginal peoples would have understood the guarantee of harvest rights as a substantive protection of their way of

$83 \quad$ Ibid. at paras. 39-40.

$84 \quad$ Goldenberg notes that "successful Aboriginal resource management occurred both before and after contact with Europeans," but that Canadian courts have often chosen to ignore the evidence of this. He suggests that one reason for courts overlooking these successful methods of ecological stewardship has to do with a general discomfort with their non-formal nature. That is, they are unwritten rules and practices. Because of the lack of formality, governments and courts have implicitly assumed that the lack of documentation means that natural resource management techniques are not well-developed: see Goldenberg, supra note 46 at 312-13.

85 See Kapashesit \& Klippenstein, supra note 60 at 929.

Ibid.

It is interesting to note that, in the American context, one author has written that the concept of resource depletion would not have been in the contemplation of any party to the treaties, and so it is not at all surprising that there is no explicit provision protecting natural resources: see Michael C. Blumm \& Jane G. Steadman, "Indian Treaty Fishing Rights and Habitat Protection: The Martinez Decision Supplies a Resounding Judicial Reaffirmation” (9 March 2009), [forthcoming in 49 Natural Resources Journal 2009], online: Social Sciences Research Network, <http://ssrn.com/abstract=1356223>. 
life, which necessarily entails the preservation of the ecosystems in which this way of life was embedded.

\section{The COUNTER-ARgument: CONSTRUING LIMITATIONS ON RESOURCE RIGHTS}

The numbered treaties contain qualifications to Aboriginal resource rights in the following terms:

[T]hey shall have the right to pursue their usual vocations of hunting, trapping and fishing throughout the tract surrendered as heretofore described, subject to such regulations as may from time to time be made by the government of the country, acting under the authority of His Majesty, and saving and excepting such tracts as may be required or taken up from time to time for settlement, mining, lumbering, trading or other purposes. $^{88}$

On its face, this clause seems to preclude the finding of a treaty right to conservation since it explicitly abrogates Aboriginal harvest rights on lands taken up for resource exploitation or "other purposes." ${ }^{89}$ However, once again there is a very strong logical and historical argument that the limitations on Aboriginal harvest rights should be given a narrow reading or ignored altogether. It is clear that a wide reading of the limitations on harvest rights would result in a virtual nullification of the rights for which First Nations entered into treaties.

Given the Crown's overarching fiduciary duty to Aboriginal peoples, it will be difficult for the Crown to argue that, in entering into treaties, it sought to secure title to Aboriginal lands without providing meaningful protection of the First Nations' subsistence activities. Indeed, it would be difficult for the Crown to make such an argument without incidentally establishing a breach of its fiduciary duty. Historical evidence surrounding the conclusion of First Nations treaties in Canada also indicates that a wide reading of the limitations would not be consistent with the honour of the Crown. With respect to Treaty 9, Macklem writes that

the record is conclusive on the fact that Aboriginal leaders believed that the treaty secured them the right to hunt, trap, and fish on ancestral lands.... An open-ended interpretation of either of the two qualifications on hunting, trapping, and fishing rights would confer an unbridled authority upon government actors to extinguish precisely that which Aboriginal signatories thought they were protecting. ${ }^{90}$

With respect to Treaty 8, Ross and Sharvit conclude:

The right to earn a livelihood from [hunting, fishing, and trapping] requires access to and preservation of wildlife resources. Though the government is permitted to take up land for lumbering, it was never contemplated that the majority of traditional lands would be taken up or occupied for resource extraction,

The James Bay Treaty (Ottawa: Queen's Printer, 1964) at 20, cited in Imai, supra note 49 at 4 [emphasis added].

89 Imai, ibid. at 4-5, has written that the "tracts taken up" treaty provisions appear "to give the government unfettered authority to pass regulations restricting hunting, trapping and fishing rights," and that governments have relied on the provisions to exploit natural resources in traditional First Nations territories. 
nor was it envisioned that habitat would be damaged or altered to the extent that treaty rights could no longer be exercised or would be severely restricted. ${ }^{91}$

In Marshall I, the Supreme Court of Canada read a negative covenant prohibiting the Mi’kmaq from trading, except at British run "truck-houses," as a positive guarantee of the Mi’kmaq right to fish and hunt commercially, based on extrinsic evidence concerning the mutual expectation of ongoing Mi'kmaq economic self-sufficiency. ${ }^{92}$ The reasoning in Marshall $I$ is equally applicable to the construction of the limitation clauses in the numbered treaties and indicates that, where the historical evidence justifies it (which will most often be the case), these clauses may be read down or read out. Indeed, some case law indicates that courts might be willing to go further than merely adopting a narrow reading of the limitation clauses. Instead, it appears that courts may be willing to consider the Crown's exercise of its rights under these clauses as prima facie infringements of the treaty rights to hunt, fish, and trap. ${ }^{93}$

\section{TESTING THE THEORY: CANADIAN CASE LAW ON TREATY RIGHTS TO CONSERVATION}

The majority of cases considering treaty rights to hunt, fish, and trap involve conflicts between the right to exploit resources, and regulations restricting or prohibiting the pertinent activities. Very few Canadian cases have considered claims to a treaty right to environmental preservation or conservation. However, those that have considered such a claim have rendered favourable decisions.

In Tsawout Indian Band, ${ }^{94}$ a treaty right to fish was invoked to protect the last remaining estuarine environment on the Saanich Peninsula in British Columbia. Pursuant to a provincial licence, Saanichton Marina Ltd. proposed to build a marina adjacent to property it owned in Saanichton Bay on Vancouver Island. The Tsawout opposed the construction of the marina arguing that it would interfere with their right to fish in Saanichton Bay, recognized by treaty in 1852. The Court agreed and granted a permanent injunction against construction of the marina. The treaty at issue contained the following fishing rights clause: "it is also understood that we are at liberty to hunt over the unoccupied lands, and to carry on our fisheries as formerly."

The Court found that the resource right granted to the First Nation by the treaty was unique. It did not amount to a proprietary interest in the sea bed nor a contractual right to a fishing ground but it did protect the First Nation against infringement of their right to carry on their traditional fishery in Saanichton Bay. The Court accepted that the construction of the marina would reduce access to the waters of the bay and would have significant adverse ecological effects on the bay, including the overall reduction of the bay's carrying capacity for fish and shellfish. On this basis the Court concluded that the marina would "derogate

\footnotetext{
Ross \& Sharvit, supra note 73 at 676 [emphasis added]. Supra note 55 at paras. 41-52.

See Halfway River First Nation v. British Columbia (Ministry of Forests), [1997] 4 C.N.L.R. 45 (B.C.S.C.) [Halfway (B.C.S.C.)].

Saanichton Marina Ltd. v. Tsawout Indian Band (1989), 57 D.L.R. (4th) 161 (B.C.C.A.) [Tsawout Indian Band].

Ibid. at para. 3 .
} 
from the right of the Indians to carry on their fisheries as formerly in the area of Saanichton Bay which is protected by the treaty." 96

The treaty in Tsawout Indian Band is distinguishable from the numbered treaties in that it contained an unqualified fishing right, and the Court seems to have relied somewhat on this condition. However, it is closely analogous to the Georgian treaties, which guaranteed the "free liberty of hunting and fishing as usual," and should be highly persuasive in cases involving those treaties. Further, the holding in Tsawout Indian Band represents the principle that pollution or degradation of a resource upon which treaty rights to harvest depend can constitute infringement of those rights. Thus, the Court implicitly found a right to conservation within the treaty right to harvest. For this reason, the case is an important precedent, as it reflects the conceptual link between conservation and harvesting rights.

This approach was adopted by the British Columbia Supreme Court in Halfway, ${ }^{97}$ a case involving Treaty 8 which contains the qualified resource rights clause found in the numbered treaties. This case concerned an application to quash a forest cutting permit relating to the Tusdzuh, the Halfway's traditional hunting territory. The Halfway invoked its Treaty 8 harvest rights to secure the conservation of the Tusdzuh environment. The First Nation's position was that logging on any part of the Tusdzuh would impact its treaty and Aboriginal rights by, inter alia, providing better access to non-Aboriginal hunters, by disturbing trails, horse corrals, and meatdrying camps, and by affecting wildlife.

Significantly, the Court adopted a narrow reading of the limitations on the hunting and fishing rights contained in Treaty 8, and was upheld in this approach on appeal. The Minister argued that the Halfway's right to hunt was a “defeasible” one, subject to the Crown's right to regulate for conservation and to "take up" land for the various resource activities named in the treaty. Thus, there was no infringement since the granting of logging permits was contemplated by the terms of the treaty and the Crown was merely exercising its own treaty right. The Minister further argued that extrinsic evidence was neither necessary nor admissible to construe the meaning of the limitation clauses. The Court disagreed and was confirmed on this point by the Court of Appeal. ${ }^{98}$

The British Columbia Supreme Court placed substantial reliance on statements of the Treaty Commissioner for Treaty 8 to the effect that the First Nations would be as free to hunt after the treaty as if they had never entered into it, holding that "any interference with the right to hunt, fish or trap constitutes a prima facie infringement of Treaty 8 rights. Because of these statements, the scope of the geographical limits on Treaty 8 rights ought to be restricted." ${ }^{99}$ The Court of Appeal upheld the finding that any interference with the right to hunt and fish constitutes a prima facie infringement, but does not appear to have relied upon the extrinsic evidence. Instead, following Sundown, the Court held that the First Nations' hunting rights and the Crown's rights to take up were "competing rights" such that the

Halfway River First Nation v. British Columbia (Ministry of Forests), 1999 BCCA 470, 178 D.L.R. (4th) 666 [Halfway (B.C.C.A.)].

Halfway (B.C.S.C.), supra note 93 at para. 101. 
exercise of the Crown's taking up right necessarily entailed a corresponding infringement of the First Nation's right to hunt. ${ }^{100}$

In considering the question of infringement, the British Columbia Supreme Court gave substantial weight to the Aboriginal interest in environmental conservation, noting that " $[t] o$ Halfway the Tusdzuh region is one of the last unspoiled areas of wilderness where they can exercise their traditional way of life. Logging even a limited area of the Tusdzuh would irrevocably change its character."101

The Court of Appeal disagreed with the characterization of the Tusdzuh as an "unspoiled" wilderness, noting that it had already been affected by oil and gas exploration. ${ }^{102}$ More significantly, the Court stated that "preferred means" should not be taken to refer to an area or the condition of an area, but rather to the methods of hunting. ${ }^{103}$ However, these disagreements did not affect the appellate court's conclusion that a prima facie infringement had indeed been made out. ${ }^{104}$ Finally, the British Columbia Supreme Court concluded that the infringement of the Halfway's treaty rights was unjustifiable under the test laid out in Sparrow, as consultation with the First Nation had been inadequate, and this conclusion was upheld by the Court of Appeal. ${ }^{105}$

The Halfway Courts did not explicitly consider whether treaty rights to hunt, fish, and trap included an implicit right to conservation. However, throughout their judgments the Courts seemed to accept, without question, that destruction of the resources at issue would result in infringement of the treaty rights to harvest. The corollary of this principle is the notion that treaty rights to harvest encompass a corresponding right to conservation of the resource. Most significantly, the judgments limit the ability of the Crown to rely on the "taking up" clause to justify the destruction or disruption of ecosystems on which protected resource activities rely.

Mikisew Cree First Nation v. Canada (Minister of Canadian Heritage) ${ }^{106}$ involved both First Nation exploitation and conservation rights. The Mikisew sought judicial review of the Minister's decision to approve construction of a winter road in Wood Buffalo National Park. The road would have required a corridor in which the use of firearms was prohibited (thus interfering with the right to exploit wildlife resources), and would also have disrupted and diminished important wildlife populations in the Mikisew's traditional hunting area (thus engaging the right to conservation). Justice Hansen, on behalf of the Federal Court, treated the direct regulatory, and the indirect environmental, impacts on the Mikisew's hunting practices as equally compelling infringements of their treaty rights.

Having heard evidence that the road would disrupt and reduce important game populations, Hansen J. found a prima facie infringement of the treaty right to hunt. ${ }^{107}$ She 
went on to find that the infringement failed the justificatory test set out in Sparrow. Significantly, she found that the objective of meeting regional transportation needs did not meet the "compelling and substantial" standard required by Sparrow. ${ }^{108}$ In the alternative, she concluded that, even if the objective was constitutionally sufficient, there had been inadequate consultation with the Mikisew. ${ }^{109}$ Thus, the Crown had not fulfilled its fiduciary duty to the Mikisew and the infringement could not be sustained. In the result, the Court quashed the Minister's decision to approve the road (an earlier injunction having already been granted pending the determination of the application).

The First Nation had argued that "any impact on the environment would have a corresponding impact on Mikisew's rights to hunt and trap in the Park due to Mikisew's reliance on the stability of the wildlife and furbearer populations." 110 Justice Hansen accepted this proposition and went further, holding that the Crown's consideration of environmental effects in general (through an environmental assessment process) was not sufficient to address the proposed infringement of the treaty right. Rather, the Crown was required to consider the specific environmental impacts which impinge upon the treaty right, in this case the impacts on the population of furbearers. ${ }^{111}$

Ultimately, Mikisew was decided at the Supreme Court of Canada on the basis of the duty to consult. ${ }^{112}$ The Supreme Court relied on the approach articulated in Haida and Taku River $^{113}$ in deciding that the federal government had not upheld the honour of the Crown. While the treaty right to hunt, fish, and trap is limited by the Crown's right to "take up" tracts of land from time to time (as well as being limited by geographical restrictions and government regulations), the Crown can only act on its right to take up tracts subject to a duty to consult with the affected First Nation and, in some cases, accommodate its concerns. $^{114}$

Although the focus on consultation as a touchstone for the constitutionality of interferences with Aboriginal environmental rights in Mikisew and similar cases is problematic (see Part IV, below), the case does represent a clear recognition of the conservation dimension of treaty rights to hunt, fish, and trap. Recognition of the right to conservation inherent in these harvest rights may trigger the duty to consult as well as strengthen the position of First Nations during consultation processes.

\section{AMERICAN CASE LAW ON TREATY RIGHTS TO CONSERVATION}

American courts have considered conservation rights incidental to treaty hunting and fishing rights, and have found that those rights encompass a right to the conservation of an adequate quantity and quality of the resources (specifically water) on which fish and game

\footnotetext{
$108 \quad$ Ibid. at paras. 109-22.

109 Ibid. at paras. 151-57.

$110 \quad$ Ibid. at para. 92.

$111 \quad$ Ibid. at para. 172.

112 Mikisew Cree First Nation v. Canada (Minister of Canadian Heritage), 2005 SCC 69, [2005] 3 S.C.R. 388 [Mikisew].

113 Taku River Tlingit First Nation v. British Columbia (Project Assessment Director), 2004 SCC 74, [2004] 3 S.C.R. 550 [Taku River].

Mikisew, supra note 112 at para. 56.
} 
rely. The right to conservation found its way into American Aboriginal law jurisprudence early in the 20th century with the United States Supreme Court's articulation of the "implied reservation of water" doctrine in Winters v. United States. ${ }^{115}$ In that case, the United States Supreme Court held that the treaty creating the Fort Belknap Reservation implicitly reserved a sufficient quantity of water to irrigate the arid reservation. The doctrine is now wellestablished in American law, and provides a strong basis for a right to conservation incidental to treaty rights to hunt and fish.

In the case of Washington, ${ }^{116}$ a United States District Court explicitly considered the question of whether the tribe's "right of taking fish incorporates the right to have treaty fish protected from environmental degradation.”117 The Court found that it did, observing that "[t]he most fundamental prerequisite to exercising the right to take fish is the existence of fish to be taken." 118 Evaluating the historical evidence surrounding negotiation of the treaty in question, the Court concluded that

\footnotetext{
there [could] be no doubt that one of the paramount purposes of the treaties in question was to reserve to the tribes the right to continue fishing as an economic and cultural way of life. It is equally beyond doubt that the existence of an environmentally-acceptable habitat is essential to the survival of the fish, without which the expressly-reserved right to take fish would be meaningless and valueless. Thus, it is necessary to recognize an implied environmental right in order to fulfill the purposes of the fishing clause. ${ }^{119}$
}

As a result, the State was under a duty to "refrain from degrading the fish habitat to an extent that would deprive the tribes of their moderate living needs." ${ }^{120}$ On appeal, the Ninth Circuit Court reversed the District Court's holding on this point in the following terms:

\begin{abstract}
Although we reject the environmental servitude created by the district court, we do not hold that the State of Washington and the Indians have no obligations to respect the other's rights in the resource. Instead, ... we find on the environmental issue that the State and the Tribes must each take reasonable steps commensurate with the resources and abilities of each to preserve and enhance the fishery when their projects threaten then-existing harvest levels. ${ }^{121}$
\end{abstract}

A year later in adjudicating a different treaty in the case of Adair ${ }^{122}$ the Ninth Circuit Court held that the treaty right to hunt and fish in question included a right to conservation of water sufficient to support the ongoing survival of the resources on which those activities depended. The Court affirmed the District Court's determination of water rights priorities, which accorded top priority to the right of the Klamath Tribe: "the Klamath Tribe is entitled to a reservation of water, with a priority date of immemorial use, sufficient to support exercise of treaty hunting and fishing rights." ${ }^{\prime 23}$ Although the Court rejected an overarching

564 U.S. 207 (1908).

United States v. Washington, 506 F. Supp. 187 (N.D. Wash. 1980) [Washington].

Ibid. at 190.

Ibid. at 203.

Ibid. at 205.

Ibid. at 208. It is interesting to note that the "moderate livelihood" approach was adopted by the Supreme Court of Canada in Marshall I in the context of the Mi'kmaq right to fish commercially: see Marshall I, supra note 55 at paras. 7, 59, 61.

$121 \quad$ United States v. Washington, 694 F.2d 1374 at 1389 (9th Cir. 1982).

122 United States v. Adair, 723 F.2d 1394 (9th Cir. 1983) [Adair].

Ibid. at 1415 [footnotes omitted]. 
"wilderness servitude" that would guarantee the level of water available at the time the treaty was concluded, it affirmed the Tribe's right to sufficient water to support a contemporary level of hunting and fishing to adequately maintain a "moderate living."124

Imai notes that there is in fact a significant body of American case law following the principle of conservation rights inherent in treaty-protected harvest rights:

For instance, ... American courts have intervened to ensure a certain water level to supply enough fish for a moderate living; to stop the construction of a dam which would have flooded a tribal fishery; to prevent the diversion of water away from a spawning habitat; and to save the habitat for mule deer to protect a treaty hunting right. Interestingly, some American courts have ordered consultation, and academic literature is beginning to address co-management as a way to implement a tribal role in off-reserve development. ${ }^{125}$

In 2007, in the context of the ongoing Washington litigation, a federal District Court judge ruled that the treaty provisions in question precluded the State from maintaining highway culverts that interfere with salmon migration, thus reducing salmon harvests below the minimum levels protected by the treaty right. ${ }^{126}$ From its review of the historical evidence surrounding the conclusion of the treaties in question, the Court concluded that "[i]t was ... the right to take fish, not just the right to fish, that was secured by the treaties." 127 Once again, however, the Court was careful to limit its finding to the specific facts before it, noting that " $\mathrm{t}$ ] his is not a broad 'environmental servitude' or the imposition of an affirmative duty to take all possible steps to protect fish runs as the State protests, but rather a narrow directive to refrain from impeding fish runs in one specific manner." ${ }^{128}$ Michael Blumm and Jane Steadman nonetheless suggest that this decision has reinvigorated the "right to habitat" case law and that more treaty interpretation cases will follow. ${ }^{129}$

In Adair, Washington, and similar cases, the American courts recognized that degradation of a resource on which a harvest activity protected by treaty depends constitutes infringement of that treaty right. That is, a right to hunt, fish, or trap necessarily requires incidental rights to an ecologically intact habitat in order to have substantive meaning. The reasoning in these cases (and the reserved water cases in general) is clearly applicable to other resource rights situations. Degradation or depletion of a forest, for example, could have an equally destructive impact on fish and game as degradation or depletion of water resources. The American case law on point should be persuasive to Canadian courts since Canadian and American courts share several key canons of treaty interpretation, including the principles that ambiguities should be resolved in favour of Aboriginal peoples and that treaties should be interpreted as they would naturally have been understood by the Aboriginal people at the time of signing. ${ }^{130}$

Ibid. See Blumm \& Steadman, supra note 87 at 6; Imai, supra note 49 at 21.

Imai, ibid. at 32-33 [footnotes omitted].

United States v. Washington, 2007 WL 2437166 (W.D. Wash. 2007) (WLeC). See Blumm \& Steadman, supra note 87 at 7. See also Rob Roy Smith, "At A Complex Crossroads: Animal Law in Indian Country” (2007) 14 Animal L. 109 at 121-23.

United States $v$. Washington, ibid. at 8 [emphasis omitted].

Ibid. at 9-10.

Blumm \& Steadman, supra note 87 at 7-8.

See Washington, supra note 116 at 194-95; Badger, supra note 50. Imai notes that the Canadian case that comes closest to the American approach is Tsawout Indian Band, supra note 94 (noting that the right to fish is based in the Douglas Treaty of 1852): see Imai, supra note 49 at 33. 


\section{The Aboriginal Rights ApProACH}

Claims to environmental protection can also be grounded in Aboriginal rights where there is no governing treaty, or where it is arguable that a treaty or land surrender failed to extinguish the Aboriginal right in issue. In Van der Peet, ${ }^{131}$ the Supreme Court established that activities that will be accorded status as Aboriginal rights are those that are elements of a "practice, custom or tradition integral to the distinctive culture of the aboriginal group claiming the right” ${ }^{132}$ In order to meet the Van der Peet test, a practice must have been a central and significant part of the distinctive Aboriginal culture in issue; the practice must have been "one of the things that truly made the society what it was." ${ }^{133}$ Further, the practice must have continuity with a practice that existed prior to contact with Europeans. ${ }^{134}$

The Van der Peet test for Aboriginal rights, with its focus on whether a particular activity was “integral to a distinctive culture," was described by some commentators as problematic in that it narrowed the focus to a single, distinctive trait that must have been present precontact. ${ }^{135}$ Recently, the Supreme Court had occasion to revisit the definitional stage of the Van der Peet test in Sappier, ${ }^{136}$ a consolidated criminal case that focused on both Aboriginal and treaty rights claims by the accused who had cut timber for personal use in New Brunswick Crown forests. John McEvoy wrote that "[i]n clarifying the Aboriginal rights concept, the Court rejected the species or resource specific approach to Aboriginal rights in favour of an activity approach which emphasizes the adjective 'Aboriginal' in the sense of a specific lifestyle." ${ }^{\prime 37}$ He suggests that Sappier is a more generous approach than the narrow "integral to a culture" test articulated in Van der Peet. ${ }^{138}$ That is, the focus on the Court's inquiry should be on the "way of life" of the Aboriginal people, rather than on an individual defining characteristic. ${ }^{139}$

Justice Bastarache, writing for the majority ${ }^{140}$ in Sappier, took the opportunity to clarify that that "there is no such thing as an aboriginal right to sustenance. Rather, [Adams ${ }^{141}$ and Côté $\left.{ }^{142}\right]$ stand for the proposition that the traditional means of sustenance, meaning the precontact practices relied upon for survival, can in some cases be considered integral to the distinctive culture of the particular aboriginal people.”143 Justice Bastarache's judgment is a double-edged sword in this regard. On the one hand, there is no such thing as an aboriginal right to sustenance, meaning that evidence of harvesting in traditional territories is insufficient to ground an aboriginal right and, therefore, also an incidental right of

$131 \quad$ Supra note 33.

$132 \quad$ Ibid. at para. 46.

133 Ibid. at para. 55 [emphasis in original].

134 Ibid. at paras. 60-62.

135 Guy C. Charlton, "Letting go of Culture: A Comment on R. v. Sappier; R. v. Gray" (2007-2008) 39 Ottawa L. Rev. 317 at 319-20.

136 R. v. Sappier; R. v. Gray, 2006 SCC 54, [2006] 2 S.C.R. 686 [Sappier].

137 John P. McEvoy, "Aboriginal Activities and Aboriginal Rights: A Comment on R. v. Sappier; R. v. Gray” (2007) 6 Indigenous L.J. 1 at 3. Note that Bastarache J. rejected the resource-specific right on the grounds that to focus on the resource would create common law property rights in the resource, a result the Court wants to avoid: see Sappier, ibid. at para. 21. McEvoy, ibid. at 2.

Ibid. at 20.

Justice Binnie wrote concurring reasons.

R. v. Adams, [1996] 3 S.C.R. 101 [Adams].

R. v. Côté, [1996] 3 S.C.R. 139 [Côté].

Sappier, supra note 136 at para. 37 [emphasis in original]. 
conservation. On the other hand, Bastarache J. emphasized that the jurisprudence favours "protecting the traditional means of survival of an aboriginal community."144 This shows clear support for the notion that an Aboriginal group should be able to sustain itself according to its traditional means, a right that is meaningless if the environment is too polluted or degraded to support traditional hunting, trapping, or fishing.

Unlike treaty rights, which derive from an agreement between a given First Nation and the Crown, Aboriginal rights arise by virtue of Aboriginal peoples' prior use and occupation of an area of land. ${ }^{145}$ Thus, arguments put forward in the treaty rights context regarding Aboriginal expectations of the Crown do not readily apply to found an Aboriginal right to environmental preservation. Rather, in the context of Aboriginal rights, the right to conservation derives from two bases.

First, Aboriginal peoples may argue, as in the treaty context, that an Aboriginal right to hunt, fish, or trap must be interpreted as including a right to conservation if the Aboriginal right is to be given any substance. The argument that rights to harvest resources are meaningless in the absence of a corresponding right to the conservation thereof applies to aboriginal rights as well as it does to treaty rights. ${ }^{146}$ Where an Aboriginal group can demonstrate that sustainable resource use is a part of its traditional culture, there will be a strong argument for interpreting the content of an Aboriginal resource right as including a right to conservation. This flows from the principle that courts must be "sensitive to the aboriginal perspective ... on the meaning of the rights at stake." ${ }^{147}$ Further, since it has been recognized that conservation and sustainable management is consistent with the enhancement of aboriginal rights, ${ }^{148}$ it follows that environmental degradation may be inconsistent with those rights.

Second, Aboriginal peoples may also enjoy a free-standing Aboriginal right to govern the environmental preservation of their lands. ${ }^{149}$ Aboriginal systems of sustainable environmental management will meet the Van der Peet test in many cases. In virtually every case, these systems will meet the requirement of being a central and significant part of the distinctive Aboriginal culture, or of being "one of the things that truly made the society what it was." 150 Indeed, self-regulation of environmental resources has been treated as a defining

Ibid. at para. 38.

Sparrow, supra note 32.

This has been noted by Morse who writes that "having a right to hunt and fish recognized by the state $\ldots$ is illusory and even meaningless if there is nothing in fact to harvest or what can be harvested is unsafe to consume": see Morse, supra note 4 at 159.

Sparrow, supra note 32 at 1078. See also Delgamuukw, supra note 38 at para. 81; Sappier, supra note 136; Van der Peet, supra note 33 at paras. 49-50; Marshall-Bernard, supra note 40 at para. 129. Sparrow, ibid. at 1113-14.

See Kapashesit \& Klippenstein, supra note 60. See also Theresa A. McClenaghan, "Why Should Aboriginal Peoples Exercise Governance Over Environmental Issues?” (2002) 51 U.N.B.L.J. 211.

Van der Peet, supra note 33 at para. 55. 
characteristic of Indigenous societies globally, ${ }^{151}$ and this is no less true with respect to Indigenous peoples in Canada.

Although Aboriginal peoples generally may not have great difficulty demonstrating that engaging in environmental preservation was integral to their culture prior to contact, there may be some difficulty in meeting the continuity requirement in many cases. As noted above, to qualify as an Aboriginal right an activity must have continuity with pre-contact practice,

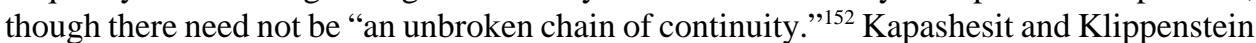
assert that Aboriginal ecological management systems, "while often severely stressed, have the ability to survive." 153 Nevertheless, it is likely that this part of the Van der Peet/Sappier test will constitute the biggest hurdle for Aboriginal peoples claiming a right to engage in environmental regulation. Despite the potential difficulty of demonstrating continuity, there is a strong argument that Aboriginal environmental governance systems persist. John Borrows explains:

\footnotetext{
Indigenous legal principles form a system of 'empirical observations and pragmatic knowledge,' which have both value in themselves, and also in demonstrating how people structure information; they embrace ecological protection and could be woven into the very fabric of North American legal ideas. Indigenous laws sometimes find their expression in traditional stories, which are a primary source to discover precedents guiding environmental and land-use planning. These narratives often pre-date the common law, have enjoyed their persuasiveness for centuries, and have yet to be overturned or extinguished from the tribal memory. Placing Indigenous traditions in an inter-societal context, through a culturally appropriate methodology that allows access to oral tradition and community knowledge, illustrates how traditional legal knowledge could enhance democracy and facilitate sustainability. ${ }^{154}$
}

Similarly, Kapashesit and Klippenstein argue that, "where a viable Aboriginal [ecological] management system exists," government has a constitutional duty to accommodate that system. ${ }^{155}$ They contend that there is an Aboriginal right to environmental preservation and that where an Aboriginal resource management system exists, it is the preferred means of exercising that right. Further, they assert that where such a system is in place, the Crown would be unable to justify externally imposed conservation legislation, since such legislation would fail the minimal impairment subtest of the Sparrow justificatory test. With respect to the nature and scope of the right to environmental self-governance, Theresa McClenaghan explains that

[a] particular right of self-government may arise from establishment of an environmental aboriginal right which in turn might imply a right of governance as to the scope of that right. Another approach would see

The United Nations Sub-Commission on Prevention of Discrimination and Protection of Minorities in its Study of the Problem of Discrimination against Indigenous Populations, UN ESCOR, 36th Sess., UN Doc. E/CN.4/Sub.2/1983/21/Add.4 (1983) at 28, appears to treat a unique relationship with land and resources as a sine qua non of Indigenous status:

[A]ll indigenous communities have, and uphold, a complete code of rules of various kinds which are applicable to the tenure and conservation of land as an important factor in the production process, the foundation of family life and the territorial basis for the existence of their people as such. The whole range of emotional, cultural, spiritual and religious considerations is present where the relationship with the land is concerned. Van der Peet, supra note 33 at para. 65.

Kapashesit \& Klippenstein, supra note 60 at 932 [footnotes omitted].

Borrows, "Living Between Water and Rocks," supra note 5 at 428-29 [footnotes omitted]. Kapashesit \& Klippenstein, supra note 60 at 960-61. 
aboriginal peoples exercising environmental governance by rule making about activities on the aboriginal peoples' “own” lands (aboriginal title or reserve lands) and about members' activities. Another possibility is to insist that neighbouring or other orders of government require persons under their jurisdiction to comply with rules to avoid specified impacts on aboriginal peoples. Canadian common law courts could enforce decisions that aboriginal peoples have made about allowable impacts on the environment of their "own" lands. ${ }^{156}$

Thus, the independent right to environmental self-government may complement conservation rights inherent in Aboriginal and treaty rights to hunt, fish, and trap.

\section{OBLIGATIONS FLOWING FROM AN IMPLiCIT RIGHT TO CONSERVATION}

A substantial body of case law focuses on the measures a government must take in order to justify infringing the rights guaranteed by s. 35 (a topic discussed in Part VI, below). However, it is useful to consider how a government might conduct itself so as to avoid a prima facie infringement of the implicit right to conservation described herein. The honour of the Crown clearly requires that governments attempt to respect the rights enshrined in $\mathrm{s}$. 35 by regulating in a way that tends to avoid interference with the substance of these rights. If we are correct in arguing that Aboriginal and treaty rights to hunt, fish, and trap encompass an implied right to conservation of the target resources, what obligations would such a right impose on government environmental decision-makers?

Without attempting an exhaustive answer to this question, it seems apparent that a s. 35 right to conservation would constrain governmental decision-makers in the issuance of permits that will affect animals and fish that are subject to s. 35 harvest (and conservation) rights. Thus, in determining appropriate levels and locations of logging, mining, oil extraction, etc., governments would have a constitutional duty to ascertain the resource needs of any potentially affected Aboriginal group and ensure that these needs will not be compromised. Similarly, in determining appropriate levels for pollution permits, governments will have to take into account the need to maintain fish and animal populations that are fit for human consumption.

In each case, this will involve consultation with the affected Aboriginal group, but consultation of a fundamentally different nature than that undertaken in the justification analysis. Rather than conceiving a plan for resource extraction, for example, and then inquiring as to how the project might be modified to work around the needs of an affected Aboriginal group, avoiding a prima facie infringement of the s. 35 right to conservation would suggest a change in the order of events. A commitment to respect the substance of s. 35 environmental rights would frequently require a government to consult with Aboriginal groups at the front end of the land use planning process, in order to ascertain what kinds of activities could be carried out on the land without interfering with the Aboriginal harvest (and correlative conservation) rights.

This approach would create additional incentives to integrate Aboriginal traditional knowledge as to the "normal" levels of a given prey population and the habitat needs of that 
fish or animal. Borrows observes that this would likely result in benefits to Aboriginal and non-Aboriginal Canadians alike:

As [the Brundtland] Commission notes, there are significant Indigenous institutions and ideas to build upon to halt the deterioration of places we call home. Allowing local Indigenous communities a democratic voice in regulating environmental rights and obligations may contribute to the improvement of human settlements. Over the centuries these peoples have enjoyed great success in meeting the needs of the present without compromising the ability of future generations to meet their own needs. ${ }^{157}$

Thus, there is much to recommend this proactive model, and there is no doubt that this approach is most consistent with the goal of reconciliation flowing from the Crown's obligations to Aboriginal peoples under s. 35. ${ }^{158}$

\section{EXTINGUISHMENT AND JUSTIFIABLE INFRINGEMENT}

Conservation rights implicit in Aboriginal and treaty rights to hunt, fish, and trap are only effective if those rights have not been extinguished by the Crown. The onus of proving extinguishment lies with the Crown and is measured according to the standard of "strict proof" of a "clear and plain intention" on the part of the Crown to extinguish the Aboriginal or treaty right to hunt, fish, and trap. ${ }^{159}$ Mere regulation of First Nations resource activity or failure to recognize and protect the Aboriginal or treaty right will not be sufficient to prove extinguishment. Aboriginal and treaty rights could not be extinguished after 1982 when they were elevated to constitutional status through s. 35(1) of the Constitution.

However, in Sparrow the Supreme Court established that governments may infringe Aboriginal rights as long as the infringement can be justified according to the two-part test laid out therein. In the first part of the test, the Court asks whether there has been interference with an Aboriginal right; if so, then there is a prima facie infringement of s. 35(1). In determining whether interference has occurred, the Court considers whether the limitation is reasonable, whether it causes undue hardship, and whether it denies the holders of the right their preferred means of exercising it. ${ }^{160}$

Once a prima facie infringement has been found, the Court moves on to the justificatory stage of the analysis. Here, the Court inquires first into the validity of the legislative objective. If there is a valid legislative objective, the Court asks whether the Crown has upheld its fiduciary duty to Aboriginal peoples in the manner in which it has infringed the right in question. According to Sparrow, considerations relevant to this inquiry include whether priority has been given to the Aboriginal right, whether there has been minimal impairment of the right, whether fair compensation has been provided in the case of

Borrows, "Living Between Water and Rocks," supra note 5 at 423 [footnotes omitted]. For an illuminating case study of how one First Nation's environmental knowledge could have contributed to sustainable land use planning, see also 437-38.

158 The Court in Haida, supra note 6, described the process of reconciliation as flowing from the Crown's obligation to deal honourably with Aboriginal peoples (para. 32); see also Taku River, supra note 110 at para. 24 . 
expropriation, and whether the Aboriginal group has been adequately consulted. ${ }^{161}$ In Côté, ${ }^{162}$ the Supreme Court established that treaty rights are equally infringeable, subject to the justificatory test laid out in Sparrow. However, it should be noted that, although provincial governments appear to have the capacity to infringe Aboriginal rights and title, ${ }^{163}$ there is no apparent legal basis for provincial infringement of treaty rights. ${ }^{164}$

Since the federal government is free to infringe Aboriginal and treaty rights provided such infringement can be justified, the net result of recognizing a constitutionally protected Aboriginal or treaty right to conservation is not absolute protection for First Nations' environments in all cases. Under the first branch of the justificatory test, courts have expanded the kinds of governmental objectives that will be adequate to withstand constitutional scrutiny to the point where virtually any legitimate public purpose may suffice. $^{165}$

As a result, very often the protection afforded by s. 35 amounts to no more than the right to procedural fairness in the manner in which infringements of Aboriginal or treaty rights are carried out (stage two of the justificatory analysis). Although foundational case law from the Supreme Court of Canada suggests that the Crown's fiduciary obligation may sometimes require compensation or even the full consent of the affected Aboriginal group, ${ }^{166}$ recent cases have tended to focus myopically on the question of consultation. ${ }^{167}$ The scope and content of the duty to consult have been thoroughly canvassed by other authors, ${ }^{168}$ but a few key characteristics bear repeating here. First, the duty is "part of a process of fair dealing and reconciliation that begins with the assertion of sovereignty and continues beyond formal claims resolution." 169 Second, the duty to consult does not require agreement between the Crown and the affected Aboriginal group. Third, while the duty to consult does not in itself require agreement, ${ }^{170}$ in some cases, a consultation process may give rise to a duty to

Ibid.

Côté, supra note 142.

See Delgamuukw, supra note 38 at para. 160.

Shin Imai, "Treaty Lands and Crown Authority: The Impact of Delgamuukw, Badger, and Marshall in Ontario" in Law Society of Upper Canada, Special Lectures 2001: Constitutional and Administrative Law (Toronto: Irwin Law, 2002) 135. The question of whether or not provinces are allowed to infringe treaty rights is currently at issue in Ontario. In Keewatin v. Ontario (Minister of Natural Resources) (2006), 32 C.P.C. (6th) 258 (Ont. S.C.), the Court granted the Grassy Meadows First Nation permission to continue its class action lawsuit against the government of Ontario. The Grassy Meadows are seeking judicial review of the Minister's decision to allow Abitibi to cut trees on treaty land. At issue in the case is whether the province has rights to "take up land" under the treaty, rights that would clearly be available to the federal Crown. The dispute is ongoing.

See generally Borrows, "Living Between Water and Rocks," supra note 5; Goldenberg, supra note 46 at 279, 285-86; McClenaghan, supra note 149 at 220-21; Kent McNeil, "How Can Infringements of the Constitutional Rights of Aboriginal Peoples be Justified?” (1997) 8 Const. Forum Const. 33 at 35. It is worth noting that Goldenberg also identifies the definitional stage of the Van der Peet test as a weakness in Canadian Aboriginal rights jurisprudence. It is this stage that has since been strengthened in Sappier. Ultimately, however, Goldenberg concludes that the justificatory step of the Sparrow test poses the bigger problem for Aboriginal rights: see Goldenberg, supra note 46 at 282-86. See also Westra, supra note 2 at 128.

See Delgamuukw, supra note 38.

See Haida, supra note 6; Mikisew, supra note 112; Taku River, supra note 113.

See e.g. Thomas Isaac \& Anthony Knox, "The Crown's Duty to Consult Aboriginal People” (2003) 41 Alta. L. Rev. 49; Heather L. Treacy, Tara L. Campbell \& Jamie D. Dickson, "The Current State of the Law in Canada on Crown Obligations to Consult and Accommodate Aboriginal Interests in Resource Development" (2007) 44 Alta. L. Rev. 571.

Haida, supra note 6 at para. 32. See also Treacy, Campbell \& Dickson, ibid. at 585.

Isaac \& Knox, supra note 168 at 68. 
accommodate the concerns and interests of Aboriginal groups. ${ }^{171}$ (This generally involves altering the manner in which the proposed project is carried out, rather than eliminating the project altogether). Fourth, the duty to consult arises even in situations where the alleged Aboriginal or treaty right has yet to be proven; Crown knowledge of the Aboriginal group's "potential" interest is sufficient to trigger the duty. ${ }^{172}$

In the aftermath of Haida, Taku River, and Mikisew, litigation over Aboriginal rights has largely been confined to the question of whether the Crown adequately discharged its duty to consult. ${ }^{173}$ This elevation of consultation as a touchstone for the constitutionality of infringements of s. 35 has been roundly criticized in the academic literature. ${ }^{174}$ The consultation requirement as articulated by the Supreme Court of Canada is a process in which the Crown sets the terms for the discussion and has the power to unilaterally impose a result. Christie has ably elucidated the essentially colonialist nature of this approach:

\begin{abstract}
When the Crown is obligated to consult with an Aboriginal nation, the consultation does not involve how this nation might see itself in relation to its lands. Nor does the consultation concern how the latter vision might inform how people in general will interact with that land. Rather, the Crown is obligated to consult about how its visions of land use will be implemented.
\end{abstract}

Do Aboriginal nations want to partake in the exploitation of their own lands by a state that thinks of land use with no acceptance of responsibilities to these lands, by a state that lacks deep cultural connections to these lands? Do Aboriginal nations want to be consulted about how their lands will be exploited? ${ }^{175}$

There is no question that a move away from the hegemony of this kind of consultation is urgently needed in Canadian Aboriginal law. Infringement of Charter rights cannot be cured by consultation with the affected individuals, and Aboriginal rights under s. 35 should receive no less protection. Canadian courts should return to the foundational question as to whether any given infringement accords with the Crown's fiduciary duty to Aboriginal peoples. In a few cases, good faith consultation may suffice to meet this basic criterion. In others, compensation or consent may be necessary. On some occasions the rights enshrined in s. 35 of the Constitution may require that a government abandon a particular project. At a minimum, any environmental infringement of s. 35 that reaches the level of a threat to health and well-being could never be justifiable under the Sparrow test. This is so because

Haida, supra note 6 at para. 47. See also Treacy, Campbell \& Dickson, supra note 168 at 587.

Treacy, Campbell \& Dickson, ibid. at 593. See also Morse, supra note 4 at 178.

In part, this may be explained by the fact that governments have set up comprehensive land claims processes and many of the alleged rights are being discussed in that context. Examples of Aboriginal claims that have been resolved using the duty to consult framework approach laid out in Haida include: R. v. Douglas, 2007 BCCA 265, 278 D.L.R. (4th) 653, leave to appeal to S.C.C. refused, 32142 (15 November 2007); Tsuu T'ina Nation v. Alberta (Minister of the Environment), 2008 ABQB 547, 96 Alta. L.R. (4th) 65; Tzeachten First Nation v. Canada (Attorney General), 2008 FC 928, 297 D.L.R. (4th) 300; Ahousaht Indian Band v. Canada (Minister of Fisheries \& Oceans), 2008 FCA 212, 297 D.L.R. (4th) 722; Native Council of Nova Scotia v. Canada (Attorney General), 2008 FCA 113, 377 N.R. 247; Chicot v. Canada (Attorney General), 2007 FC 763, 314 F.T.R. 178; Saulteau First Nations v. British Columbia (Oil \& Gas Commission), 2004 BCCA 286, 201 B.C.A.C. 78. 
such an infringement could never comport with the Crown's fiduciary duty to First Nations peoples. Thus, the finding of an Aboriginal or treaty right to conservation should at least operate to prevent or remedy the most egregious cases of environmental degradation on First Nations' lands. ${ }^{176}$

Even in cases where courts remain focused on the question of consultation, this minimal constitutional protection may still result in significant practical gains, as was the case in Halfway, Haida, Taku River, and Mikisew where governmental decisions, which would have resulted in serious environmental degradation on Aboriginal lands, were quashed for failure to adequately consult the relevant First Nations. Furthermore, if the requirement of "meaningful" consultation is given a liberal interpretation, it is at least theoretically capable of enfranchising Aboriginal peoples in decision-making processes that have historically been closed to them. ${ }^{177}$ Where the duty to consult is found to give rise to an obligation to accommodate, destructive development or resource use may be slowed, mitigated, or prevented altogether. Recognition of a requirement to compensate Aboriginal peoples, or obtain full consent before proceeding, would provide more meaningful protection for the environmental rights enshrined under s. 35.

\section{CONCLUSION}

In sum, there is substantial support for the notion of a right to conservation implicit in Aboriginal and treaty rights to hunt, fish, and trap. The treaty right flows from the canons of treaty interpretation established by the Supreme Court in conjunction with the specific histories of treaty-making in Canada. The critical concept here is the proposition that treaty guarantees of hunting, fishing, and trapping rights amounted to a right to continue traditional Aboriginal ways of life. The Aboriginal right to conservation can be founded in two ways: first, it can be seen as necessary to give meaning to the Aboriginal rights to hunt, fish, and trap; and second, it can arise from a free-standing Aboriginal right to engage in environmental preservation in traditional territories.

An Aboriginal or treaty right to conservation would constrain governmental decisionmakers engaged in issuing permits or licenses that would affect animals and fish subject to s. 35 harvest rights. The Crown would have a constitutional duty to determine the resource needs of potentially affected Aboriginal groups before allowing natural resource extraction or development projects, and this would extend to a requirement that the Crown take into account the quality of the animals and fish available to ensure that they are fit for human consumption.

In order to derive the benefit of an Aboriginal or treaty right to conservation, the right in question must not have been extinguished prior to 1982. Further, given the Crown's power of justifiable infringement, the practical effect of an Aboriginal or treaty right to conservation poisoning of fish stocks caused by industrial effluent released into the Grassy Narrows First Nation's fishing areas: see "Mercury Rising: The Poisoning of Grassy Narrows" CBC News (1 November 1970) online: CBC Digital Archives <http://archives.cbc.ca/environment/pollution/topics/1178/>. See also examples at supra notes 11-18 and related text. 
will often be limited to greater consultation, especially given the prominence of the duty to consult doctrine in contemporary Canadian jurisprudence. However, such a right should operate to prevent environmental harm on Aboriginal land that is serious enough to constitute a threat to life, health, or the cultural survival of the group.

In his insightful analysis of Indigenous rights as a mechanism to achieve environmental protection, Bradford Morse writes that despite the many cases recognizing incidental rights necessary to give meaning to Aboriginal harvest rights, there are "precious few examples where these ancillary rights have been used as the foundation to argue that a right to gather flora and fauna must entail the presence of the substances themselves and in a condition in which they can be safely consumed." ${ }^{178} \mathrm{He}$ confirms, however, that "[t]he legal basis to make such arguments remains available." ${ }^{\text {"179 }}$ The foregoing analysis represents an attempt to articulate this basis in the Canadian law of Aboriginal and treaty rights to hunt, fish, and trap. It is our hope that this legal theory may assist Aboriginal peoples, and Canadian society more generally, in achieving environmental justice in Aboriginal territory and beyond. 